\title{
Seasonal characterization of sugarcane vinasse: Assessing environmental impacts from fertirrigation and the bioenergy recovery potential through biodigestion
}

\author{
Lucas Tadeu Fuess $^{\mathrm{a}, *}$, Marcelo Loureiro Garcia ${ }^{\mathrm{b}}$, Marcelo Zaiat ${ }^{\mathrm{a}}$ \\ a Biological Processes Laboratory (LPB), São Carlos School of Engineering (EESC), University of São Paulo (USP), Av. João Dagnone, 1100, Santa Angelina, São Carlos, São Paulo 13563-120, Brazil \\ b São Paulo State University (UNESP), Institute of Geosciences and Exact Sciences (IGCE), Campus of Rio Claro. Av. 24-A, 1515, Bela Vista, Rio Claro, São Paulo 13506-900, Brazil
}

\section{H I G H L I G H T S}

- Vinasse streams were characterized throughout the sugarcane harvest period.

- The fate of vinasse through fertirrigation and anaerobic digestion was assessed.

- The organic polluting load could be reduced by $80 \%$ through two-phase biodigestion.

- Over 300 thousand inhabitants could be supplied with biogas electricity.

- Sodium accumulation would severely limit the land disposal of biodigested vinasse.

\section{GRA P H I C A L A B S T R A C T}

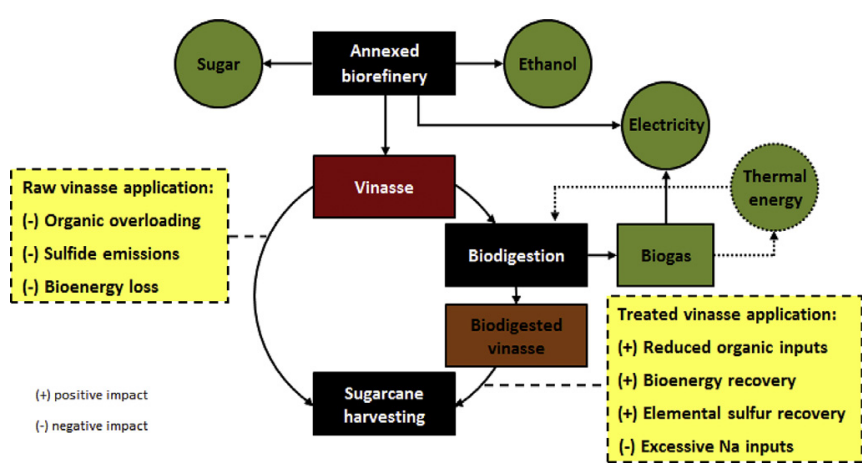

\section{A B S T R A C T}

Sugarcane vinasse has been widely used as a soil fertilizer in the Brazilian sucro-alcohol industry for recycling potassium and water. However, the potential negative effects from long-term soil fertirrigation represent a major drawback regarding this practice, whereas the application of biodigestion represents an efficient method for reducing the polluting organic load and recovering bioenergy from vinasse. Regardless of the predicted use for vinasse, an understanding of the potential of each option is imperative, as the seasonal alterations in the inorganic/organic fractions of vinasse directly affect its management. In this context, this study presents a detailed compositional characterization of sugarcane vinasse from a large-scale Brazilian biorefinery throughout the 2014/2015 harvest to assess the environmental effects (due to fertirrigation) and to estimate the biogas energetic potential. Calculated inputs of organic matter into soils due to vinasse land application were equivalent to the polluting load of populations $\left(117-257\right.$ inhab ha $\left.^{-1}\right)$ at least 2-fold greater than the largest Brazilian capital cities (78-70 inhab ha ${ }^{-1}$ ). Two-phase biodigestion could efficiently reduce the polluting load of vinasse (23-52 inhab ha ${ }^{-1}$ ) and eliminate the negative effects from direct sulfide emissions in the environment. However, a high risk of soil sodification could result from using high doses of Na-based alkalizing compounds in biodigestion plants. Finally, the optimized recovery of bioenergy through biogas (13.3-26.7 MW as electricity) could supply populations as large as 305 thousand inhabitants, so that over $30 \%$ of the surplus electricity produced by the studied biorefinery could be obtained from biogas. Overall, applying biodigestion in the treatment of vinasse provides important environmental and energetic gains. However, the benefits of reducing the polluting organic load of vinasse through bioenergy recovery may lose their effect depending on the alkalizing strategy, indicating that the proper use of chemicals in full-scale biodigestion plants is imperative to attain process sustainability.

(c) 2018 Elsevier B.V. All rights reserved.

\footnotetext{
* Corresponding author.

E-mail addresses: Itfuess@alumni.usp.br, (L.T. Fuess), mlgarcia@rc.unesp.br, (M.L. Garcia), zaiat@sc.usp.br. (M. Zaiat).
} 


\begin{tabular}{|c|c|}
\hline \multicolumn{2}{|c|}{ Nomenclature } \\
\hline$[\mathrm{K}]_{\text {soil }}$ & concentration of potassium in the soil \\
\hline$[\mathrm{K}]_{\text {vinasse }}$ & $\begin{array}{l}\text { concentration of potassium in vinasse } \\
{\left[\mathrm{NaHCO}_{3}\right] \text { sodium bicarbonate dose }}\end{array}$ \\
\hline$[\mathrm{NaOH}]$ & sodium hydroxide dose \\
\hline $\mathrm{AD}$ & anaerobic digestion \\
\hline $\mathrm{AOL}_{\text {soil }}$ & applied organic load into the soil \\
\hline BOD & biochemical oxygen demand \\
\hline & $\mathrm{BOD}_{\text {sewage }}$ BOD of sewage \\
\hline & $\mathrm{BOD}_{\text {vinasse }} \mathrm{BOD}$ of vinasse \\
\hline CEC & cation exchange capacity \\
\hline COD & chemical oxygen demand \\
\hline & $\mathrm{COD}_{\text {sewage }} \mathrm{COD}$ of sewage \\
\hline & $\mathrm{COD}_{\text {vinasse }} \mathrm{COD}$ of vinasse \\
\hline CR & sewage-to-water return coefficient \\
\hline EP & energetic potential of biogas \\
\hline EqPop & equivalent population \\
\hline $\mathrm{ER}_{\mathrm{COD}}$ & COD removal in biodigestion \\
\hline GHG & greenhouse gas \\
\hline HP & harvesting period \\
\hline HSW & high-strength wastewater \\
\hline HY & hydrogen yield \\
\hline ICE & internal combustion engine \\
\hline $\mathrm{LHV}_{\mathrm{CH} 4}$ & lower heating value of methane \\
\hline $\mathrm{LHV}_{\mathrm{H} 2}$ & lower heating value of hydrogen \\
\hline $\mathrm{M}_{\mathrm{HS}-}$ & molar mass of sulfide \\
\hline $\mathrm{M}_{\mathrm{SO} 4}$ & molar mass of sulfate \\
\hline MTC & million tons of sugarcane \\
\hline MY & methane yield \\
\hline & $\mathrm{Na}_{\text {vin }}^{\text {biod }}$ concentration of sodium in the biodigested \\
\hline vinasse & \\
\hline & $\mathrm{Na}_{\text {vin }}^{\text {raw }}$ concentration of sodium in raw vinasse \\
\hline & $\mathrm{PCC}_{\text {water }}$ per capita water consumption \\
\hline pHPR & potential hydrogen production rate \\
\hline pMPR & potential methane production rate \\
\hline pSE & potential sulfide emission \\
\hline SAR & sodium adsorption ratio \\
\hline S-COD & soluble COD ( $0.45 \mu \mathrm{m}$-filtered samples) \\
\hline TC & tons of sugarcane \\
\hline T-COD & total COD (unfiltered samples) \\
\hline TKN & total Kjeldahl nitrogen \\
\hline TOC & total organic carbon \\
\hline TRS & total reducing sugar \\
\hline VFA & volatile fatty acids \\
\hline VFR & vinasse flow rate \\
\hline VinAR & vinasse application rate \\
\hline$\eta$ & energy conversion factor \\
\hline
\end{tabular}

\section{Introduction}

The fate of vinasse, the primary wastewater from ethanol production, represents one of the main burdens of the sucro-alcohol industry in Brazil. In the mid-1970s, restrictive laws prohibited the direct and indirect discharge of vinasse into water bodies (Fuess and Garcia, 2014; Moraes et al., 2015), which promptly encouraged the land disposal of this high-strength wastewater (HSW) through fertirrigation by recycling nutrients, primarily potassium, and water to the sugarcane fields (Dias et al., 2015). Despite the proven techno-economic feasibility of fertirrigation (Cruz et al., 2013), the continuous long-term land disposal of vinasse into soils has great potential to trigger a series of negative environmental effects (Fuess and Garcia, 2014; Fuess et al., 2017c), such as soil salinization and the subsequent structural destabilization of the terrain, microbial activity losses, and the permanent acidification of soils and water resources. These effects are the direct results of the high inputs of salts and biodegradable organic compounds, particularly organic acids, into the fields.

Anaerobic digestion $(A D)$ or biodigestion may be considered the primary alternative for managing vinasse in sugarcane biorefineries. AD has important advantages over fertirrigation, including a reduction in the polluting organic load of vinasse, the potential recovery of bioenergy from biogas, and the potential for enhancing the profitability of biorefineries through the generation of surplus electricity, based on the burning of biogas in prime movers (Fuess and Garcia, 2015; Fuess et al., 2018; Moraes et al., 2014, 2015). Moreover, the removal of nutrients in AD systems is negligible, which means that the fertilizing potential of in natura vinasse is maintained in the biodigested effluents (Moraes et al., 2015; Salomon et al., 2011). Additional technological approaches proposed for the management of vinasse include the cultivation of microbial biomass for the production of protein-rich cells (Pires et al., 2016; Santos et al., 2016), which may also be coupled to the recovery of different bioproducts, such as bioemulsifiers (Colin et al., 2016; Oliveira and Garcia-Cruz, 2013), enzymes (Kahraman and Gurdal, 2002), and lipids (Fernandes et al., 2017). The recycling of vinasse into the fermentation step has also been shown as an efficient destination for this HSW, aiming at the production of fuel ethanol (Navarro et al., 2000) and spirits (Menezes et al., 2013).

Regardless of the chosen use for sugarcane vinasse, it is imperative to understand the potential of each available application through a complete compositional characterization of vinasse, as seasonal alterations in the inorganic and organic fractions of this HSW directly affect the proposed management approaches. With respect to fertirrigation in Brazil, the concentration of nutrients in vinasse, particular that of potassium, defines the application rates into the sugarcane fields (CETESB, 2015), resulting in other environmental impacts from the associated inputs of biodegradable organic matter (the polluting organic load) and other constituents. In turn, biodigestion is directly affected by the biodegradability of the organic fraction from vinasse as well as by the accumulation of specific inhibitory/interfering compounds, such as phenols and sulfate.

In this context, this study aimed to present a detailed compositional characterization of sugarcane vinasse from a large-scale Brazilian biorefinery (with a milling capacity of $9.3 \times 10^{6}$ tons of sugarcane (TC) per harvest) throughout the 2014/2015 harvest, particularly for the year 2014. The organic and inorganic fractions of vinasse were characterized over seven months (May to December), and the compositional data were used to predict the environmental effects (due to fertirrigation) and to estimate the energetic potential of biogas. The impacts of the specific constituents of vinasse, such as sodium and sulfate, were considered in each case. Estimates on the application of biodigestion considered single- and two-phase schemes in an effort to understand how the polluting and energetic potentials of sugarcane vinasse could be affected throughout the harvest by applying different treatment approaches. Full-scale experiences with sugarcane biodigestion are still scarce in the Brazilian sucro-alcohol industry (Fuess et al., 2017a), minimizing field data availability and, consequently, requiring simulation- and estimate-based studies to properly understand the pros and cons of $\mathrm{AD}$. In this sense, the results obtained herein may be used as a reference for the implementation of specific management approaches in biorefineries to prevent negative effects from the use of vinasse as a fertilizer and bioenergy source.

\section{Methods}

\subsection{Sugarcane vinasse sampling and characterization}

Sugarcane vinasse samples were regularly collected from an annexed full-scale biorefinery located in the State of São Paulo, Brazil, 
throughout 2014. Annexed biorefineries produce sugar (from juice) and ethanol (from blends of juice and molasses, a byproduct from sugar production). The milling capacity of the biorefinery during the sampling period corresponded to $9.3 \times 10^{6} \mathrm{TC}$, with $48 \%$ and $52 \%$ of the total reducing sugar (TRS) content directed to sugar and ethanol production, respectively, on average. The sampling was conducted over seven months, i.e., from May to December, and the characterization was based on the following parameters: biochemical (BOD) and chemical (COD) oxygen demands, total organic carbon (TOC), and soluble organic compounds (i.e., volatile fatty acids - VFA - and solvents) for the organic fraction and nutrients and trace metals for the inorganic fraction. Nitrogen (as total Kjeldahl nitrogen, TKN), potassium (K), phosphorus $(\mathrm{P})$, calcium $(\mathrm{Ca})$, magnesium $(\mathrm{Mg})$, and sulfate $\left(\mathrm{SO}_{4}^{2-}\right)$ were assessed as nutrients, whereas sodium $(\mathrm{Na})$, cobalt $(\mathrm{Co})$, nickel $(\mathrm{Ni})$, zinc $(\mathrm{Zn})$, copper $(\mathrm{Cu})$, lead $(\mathrm{Pb})$, cadmium $(\mathrm{Cd})$, chromium $(\mathrm{Cr})$, iron $(\mathrm{Fe})$, and manganese $(\mathrm{Mn})$ were assessed as trace metals.

The BOD, COD, and TOC measurements were performed according to the procedures described in the Standard Methods for the Examination of Water and Wastewater (APHA et al., 2012): methods 5210 B (5-Day BOD Test), 5220 D (Closed Reflux, Colorimetric Method), and 5310 B (High-Temperature Combustion Method), respectively. COD analyses included the total (T-COD) and soluble (S-COD) fractions; the samples were passed through $0.45-\mu \mathrm{m}$ filters prior to S-COD measurements. VFA were analyzed by high-performance liquid chromatography according to the conditions described by Santos et al. (2014a). In this case, the samples were passed through $0.22-\mu \mathrm{m}$ filters prior to the measurements. Solvents were complementarily analyzed by gas chromatography, as proposed by Adorno et al. (2014). TKN measurements were based on semi-automated colorimetry (method 351.2 - EPA, 1993), whereas the determination of the major nutrients ( $\mathrm{K}, \mathrm{P}, \mathrm{Ca}$, and $\mathrm{Mg}$ ) and selected metals ( $\mathrm{Na}, \mathrm{Co}, \mathrm{Ni}, \mathrm{Zn}, \mathrm{Cu}, \mathrm{Pb}, \mathrm{Cd}, \mathrm{Cr}$, Fe, and $\mathrm{Mn}$ ) was performed using atomic absorption spectrometry (AAS). The samples were first subjected to microwave-assisted acid digestion (method 200.2; EPA, 1994) and then analyzed using a spectrometer (model 240FS AA, Varian Inc., Palo Alto, CA, USA) via method 200.9 (EPA, 1998). The $\mathrm{SO}_{4}^{2-}$ concentrations were determined by ionic chromatography (Dionex ICS-5000, Thermo Fisher Scientific Inc., Sunnyvale, CA, USA) using an ion suppressor and a conductivity detector, as described by Costa and Foresti (2014).

\subsection{Basic input data: sugarcane biorefinery and $A D$ systems}

The basic input data used in the estimates are compiled in Table 1, including assumptions for the biorefinery (ethanol yield, specific vinasse generation, vinasse flow rate, and harvesting period) and $A D$ systems. Performance data for the biodigestion of vinasse considered both single- and two-phase systems, which were characterized by a single methanogenic reactor and by sequential acidogenic and methanogenic reactors, respectively. Reference data for the single-phase AD system were obtained from Ferraz Jr. et al. (2016). The performance of the acidogenic and methanogenic steps of the two-phase AD scheme was based on the findings reported by Fuess et al. (2016) and Fuess et al. (2017a), respectively, to include the potential biohydrogen production from acidogenesis. The characteristics of the soils potentially suitable for fertirrigation and of the prime movers used for the production of bioenergy from biogas are also presented in Table 1.

\subsection{Fertirrigation: calculations and impact prediction}

The experimental results were first used to calculate the maximum vinasse application rate (VinAR) into soils, based on the methodology proposed by CETESB (2015) (Eq. (1)). This methodology determines the application rate of sugarcane vinasse into soils according to the $\mathrm{K}$ content in both effluent and soil. The characteristics of two different types of soils used in the cultivation of sugarcane, in terms of the potassium content and cation exchange capacity (CEC) (Table 1), were considered in the calculations. In Eq. (1), the terms VinAR, CEC, $[\mathrm{K}]_{\text {soil, }}$, and $[\mathrm{K}]_{\text {vinasse }}$ are the application rate of sugarcane vinasse $\left(\mathrm{m}^{3} \mathrm{ha}^{-1}\right)$, the CEC of the soil $\left(\mathrm{cmolc} \mathrm{dm}^{-3}\right)$, the $\mathrm{K}$ concentration in the soil at a depth of up to $0.8 \mathrm{~m}\left(\mathrm{cmolc} \mathrm{dm}^{-3}\right)$, and the $\mathrm{K}$ concentration in sugarcane vinasse $\left(\mathrm{kg}-\mathrm{K}_{2} \mathrm{O} \mathrm{m}^{-3}\right)$, respectively. The constant value 3744 is a correction factor for converting the $\mathrm{K}$ concentrations from cmolc $\mathrm{dm}^{-3}$ to $\mathrm{kg}$ per a volume of $8000 \mathrm{~m}^{3}$ ( 1 ha $\times 0.8 \mathrm{~m}$ ). The constant value 185 corresponds to the mass of $\mathrm{K}_{2} \mathrm{O}$ extracted by the crop per hectare during the harvest. $\mathrm{K}_{2} \mathrm{O}$ concentrations in vinasse were estimated by correcting $\mathrm{K}$ levels analytically determined (Section 2.1) by a factor of 1.2 , i.e., every gram of $\mathrm{K}$ corresponds to $1.2 \mathrm{~g}$ of $\mathrm{K}_{2} \mathrm{O}$.

$\operatorname{Vin} A R=\frac{\left(0.05 \cdot C E C-[K]_{\text {soil }}\right) \cdot 3,744+185}{[\mathrm{~K}]_{\text {vinasse }}}$

The application rates were used to estimate the inputs of organic matter and specific ions into the soil to highlight the impacts of the treatment processes on the vinasse quality. The inputs of organic matter were estimated through the applied organic load into the soil $\left(\mathrm{AOL}_{\text {soil }}\right)$ according to Eqs. (2) and (3) for raw and biodigested vinasse, respectively. $\mathrm{AOL}_{\text {soil }}$ values were further used to estimate the populations with a polluting potential equivalent to sugarcane vinasse (EqPop), as indicated by Eqs. (4) and (5) for raw and biodigested vinasse, respectively. In Eqs. (2) to (5), the terms AOL $\mathrm{L}_{\text {soil }}$, VinAR, BOD $\mathrm{D}_{\text {vinasse, }} \mathrm{ER}_{\mathrm{COD}}$, $\mathrm{COD}_{\text {vinasse, }}$ EqPop, $\mathrm{BOD}_{\text {sewage, }} \mathrm{COD}_{\text {sewage}}, \mathrm{PCC}_{\text {water }}, \mathrm{CR}$, and HP are the applied organic load into the soil ( $\mathrm{kg}-\mathrm{BOD} \mathrm{ha}^{-1}$ or kg-COD ha $\left.{ }^{-1}\right)$, the application rate of vinasse $\left(\mathrm{m}^{3} \mathrm{ha}^{-1}\right)$, the BOD of vinasse $\left(\mathrm{kg} \mathrm{m}^{-3}\right)$, the COD removal in biodigestion (dimensionless), the COD of vinasse $\left(\mathrm{kg} \mathrm{m}^{-3}\right.$ ), the equivalent population (inhab ha-1), the BOD of sewage $\left(\mathrm{kg} \mathrm{m}^{-3}\right)$, the COD of sewage $\left(\mathrm{kg} \mathrm{m}^{-3}\right)$, the per capita water consumption $\left(\mathrm{m}^{3}\right.$ inhab $^{-1} \mathrm{day}^{-1}$ ), the sewage-to-water return coefficient (dimensionless), and the harvesting period (days), respectively. The values for $\mathrm{BOD}_{\text {vinasse }}$ (raw vinasse) were experimentally obtained (Section 2.1), whereas the values for $\mathrm{COD}_{\text {vinasse }}$ (biodigested vinasse) were estimated from both the COD measurements (section 2.1) and the removal levels assumed for the biodigestion systems (Table 1). The values for $\mathrm{BOD}_{\text {sewage }}, \mathrm{COD}_{\text {sewage }}, \mathrm{PCC}_{\text {water }}$, and $\mathrm{CR}$ were set to $0.3 \mathrm{~kg} \mathrm{~m}^{-3}, 0.6 \mathrm{~kg} \mathrm{~m}^{-3}, 0.225 \mathrm{~m}^{3}$ inhab $^{-1}$ day $^{-1}$, and 0.8 , respectively, as reported by von Sperling (2007). The reference values for the per capita load, i.e., the potential polluting contribution of each inhabitant were $0.054 \mathrm{~kg}-\mathrm{BOD}$ inhab $^{-1} \mathrm{day}^{-1}$ (raw vinasse) and $0.108 \mathrm{~kg}$ COD inhab ${ }^{-1}$ day $^{-1}$ (biodigested vinasse).

$$
\begin{aligned}
& \mathrm{AOL}_{\text {soil }}=\operatorname{VinAR} \cdot \mathrm{BOD}_{\text {vinasse }} \\
& \mathrm{AOL}_{\text {soil }}=\operatorname{VinAR} \cdot\left(1-\mathrm{ER}_{\mathrm{COD}}\right) \cdot \mathrm{COD}_{\text {vinasse }} \\
& \mathrm{EqPop}=\frac{\mathrm{AOL}_{\text {soil }}}{\mathrm{BOD}_{\text {sewage }} \cdot \mathrm{PCC}_{\text {water }} \cdot \mathrm{CR} \cdot \mathrm{HP}} \\
& \mathrm{EqPop}=\frac{\mathrm{AOL}_{\text {soil }}}{\mathrm{COD}_{\text {sewage }} \cdot \mathrm{PCC}_{\text {water }} \cdot \mathrm{CR} \cdot \mathrm{HP}}
\end{aligned}
$$

The compositional data were also used to estimate the sodium adsorption ratio (SAR; Eq. (6)) resulting from the application of vinasse, either raw or biodigested, into the soil through fertirrigation. Unbalanced conditions between $\mathrm{Na}$ and bivalent ions, particularly $\mathrm{Mg}$ and $\mathrm{Ca}$, increase soil instability due to the dispersive characteristics of $\mathrm{Na}$ (WHO, 2006). In Eq. (6), the terms SAR, Na, Ca, and Mg are the SAR (dimensionless) and the concentrations of sodium ( $\mathrm{mEq} \mathrm{L}^{-1}$ ), calcium ( $\mathrm{mEq} \mathrm{L}^{-1}$ ) and magnesium ( $\mathrm{mEq} \mathrm{L}^{-1}$ ), respectively. With respect to biodigested vinasse, the inputs of Na were estimated from the use of Na-based alkalizing compounds (Table 1), as presented in Eqs. (7) and (8) for single- and two-phase AD systems, respectively. The terms $\mathrm{Na}_{\text {vin }}^{\text {biod }}, \mathrm{Na}_{\text {vin }}^{\text {raw }},[\mathrm{NaOH}]$, and $\left[\mathrm{NaHCO}_{3}\right]$ are the concentrations of $\mathrm{Na}$ in the biodigested and raw vinasse $\left(\mathrm{g} \mathrm{L}^{-1}\right)$, the dose of $\mathrm{NaOH}$ applied to 
Table 1

Input data for the biorefinery, biodigestion systems, bioenergy recovery systems, and fertirrigated soils.

\begin{tabular}{|c|c|c|}
\hline Input data & & Reference \\
\hline Biorefinery & $\begin{array}{l}\text { Harvesting period }=210 \text { days } \\
\text { Milling capacity }=9.3 \times 10^{6} \mathrm{TC}_{\text {harvest }}{ }^{-1} \\
\text { Ethanol yield }=53.4 \mathrm{~L} \mathrm{TC}^{-1} \\
\text { Specific vinasse generation }=10 \mathrm{~L}_{\text {vinasse }} \mathrm{L}^{-1} \text { ethanol } \\
\text { Annual ethanol production }=496,620 \mathrm{~m}^{3} \\
\text { Ethanol flow rate }=98.54 \mathrm{~m}^{3} \mathrm{~h}^{-1}\left(2364.86 \mathrm{~m}^{3} \text { day }^{-1}\right) \\
\text { Annual vinasse production }=4,966,200 \mathrm{~m}^{3} \\
\text { Vinasse flow rate }=985.40 \mathrm{~m}^{3} \mathrm{~h}^{-1}\left(23,648.60 \mathrm{~m}^{3} \text { day }^{-1}\right)\end{array}$ & $\begin{array}{l}- \\
\text { Moraes et al. }(2014) \\
\text { Moraes et al. }(2014) \\
- \\
- \\
- \\
-\end{array}$ \\
\hline Single-phase AD system (methanogenic phase) & $\begin{array}{l}\text { COD removal }=60.7 \% \\
\text { Methane yield }=0.234 \mathrm{Nm}^{3}-\mathrm{CH}_{4} \mathrm{~kg}^{-1} \mathrm{COD}_{\text {removed }} \\
\mathrm{NaHCO}_{3} \text { dose }=12.5 \mathrm{~g} \mathrm{~L}^{-1} \text { vinasse }\end{array}$ & Ferraz Jr. et al. (2016) \\
\hline Two-phase AD system (acidogenic phase) & $\begin{array}{l}\text { COD removal }=20.0 \% \\
\text { Hydrogen yield }=0.87 \text { mmol- } \mathrm{H}_{2} \mathrm{~g}^{-1} \mathrm{COD}_{\text {influent }}\left(0.0195 \mathrm{Nm}^{3}-\mathrm{H}_{2} \mathrm{~kg}^{-1} \mathrm{COD}_{\text {influent }}\right) \\
\mathrm{NaOH} \text { dose }=1.25 \mathrm{~g} \mathrm{~L}^{-1} \text { vinasse }\end{array}$ & Fuess et al. (2016) \\
\hline Two-phase AD system (methanogenic phase) & $\begin{array}{l}\text { COD removal }=73.9 \% \\
\text { Methane yield }=0.301 \mathrm{Nm}^{3}-\mathrm{CH}_{4} \mathrm{~kg}^{-1} \mathrm{COD}_{\text {removed }} \\
\mathrm{NaHCO}_{3} \text { dose }=6.25 \mathrm{~g} \mathrm{~L}^{-1} \text { vinasse }\end{array}$ & Fuess et al. (2017a) \\
\hline Soil \#1 (dystrophic red latosol) ${ }^{\mathrm{a}}$ & $\begin{array}{l}\text { Potassium content }=19.6 \mathrm{mg} \mathrm{dm}^{-3}\left(0.05 \mathrm{cmolc} \mathrm{dm}^{-3}\right) \\
\text { Cation exchange capacity }=3.23 \mathrm{cmolc} \mathrm{dm}^{-3}\end{array}$ & Zolin et al. (2011) \\
\hline Soil \#2 (dystrophic red latosol) ${ }^{b}$ & $\begin{array}{l}\text { Potassium content }=54.7 \mathrm{mg} \mathrm{dm}^{-3}\left(0.14 \mathrm{cmolc} \mathrm{dm}^{-3}\right) \\
\text { Cation exchange capacity }=4.19 \mathrm{cmolc} \mathrm{dm}^{-3}\end{array}$ & \\
\hline Bioenergy recovery systems & $\begin{array}{l}\text { Lower heating value }\left(\mathrm{H}_{2}\right)=120 \mathrm{MJ} \mathrm{kg}^{-1}\left(10.71 \mathrm{MJ} \mathrm{Nm}^{-3}\right) \\
\text { Lower heating value }\left(\mathrm{CH}_{4}\right)=50 \mathrm{MJ} \mathrm{kg}^{-1}\left(35.72 \mathrm{MJ} \mathrm{Nm}^{-3}\right) \\
\text { Electric conversion factor }=0.43(\mathrm{ICE}) \\
\text { Thermal energy conversion factor }=0.51 \text { (ICE) } \\
\text { Electric conversion factor }=0.40 \text { (fuel cell) } \\
\text { Thermal energy conversion factor }=0.30 \text { (fuel cell) }\end{array}$ & $\begin{array}{l}\text { Heywood (1988) } \\
\text { Heywood (1988) } \\
\text { J620 GS-F12 (GE Jenbacher GmbH \& Co) } \\
\text { J620 GS-F12 (GE Jenbacher GmbH \& Co) } \\
\text { Goldstein et al. (2003) } \\
\text { Goldstein et al. (2003) }\end{array}$ \\
\hline
\end{tabular}

Notes:

a Without the application of organic/inorganic fertilization.

b After 20 consecutive applications of vinasse at a dose of $150 \mathrm{~m}^{3} \mathrm{ha}^{-1}$ per year (one application per year).

the raw vinasse prior to acidogenesis ( $\mathrm{g} \mathrm{L}^{-1}$, Table 1 ), and the dose of $\mathrm{NaHCO}_{3}$ applied either to raw or acidified vinasse ( $\mathrm{g} \mathrm{L}^{-1}$, Table 1$)$, respectively. The constant values 0.2738 and 0.5750 are the corresponding proportions $(\mathrm{m} / \mathrm{m})$ of $\mathrm{Na}$ in $\mathrm{NaHCO}_{3}$ and $\mathrm{NaOH}$.

$\mathrm{SAR}=\frac{\mathrm{Na}}{\sqrt{(\mathrm{Ca}+\mathrm{Mg}) / 2}}$

$\mathrm{Na}_{\text {vin }}^{\text {biod }}=\mathrm{Na}_{\text {vin }}^{\text {raw }}+\left[\mathrm{NaHCO}_{3}\right] \cdot 0.2738$

$\mathrm{Na}_{\text {vin }}^{\text {biod }}=\mathrm{Na}_{\text {vin }}^{\mathrm{raw}}+[\mathrm{NaOH}] \cdot 0.5750+\left[\mathrm{NaHCO}_{3}\right] \cdot 0.2738$

Potential sulfide emissions were also estimated from the compositional data measured for vinasse, based on the reduction of sulfate into sulfide under anaerobic conditions (Reaction (1); Zhou and Xing, 2015). Eq. (9) presents the calculation for the potential sulfide emission ( $\mathrm{pSE}$; $\mathrm{kg} \mathrm{ha}^{-1}$ ) in which the terms $\mathrm{SO}_{4}^{2-}, \mathrm{M}_{\mathrm{HS}-}$, and $\mathrm{M}_{\mathrm{SO} 4}$ are the concentrations of sulfate directly measured in vinasse $\left(\mathrm{kg} \mathrm{m}^{-3}\right)$, the molar mass of sulfide $\left(33.07 \mathrm{~g} \mathrm{~mol}^{-1}\right.$ ), and the molar mass of sulfate (96.06 $\left.\mathrm{g} \mathrm{mol}^{-1}\right)$, respectively.

$\mathrm{SO}_{4}{ }^{2-}+$ Acetate $\rightarrow \mathrm{HS}^{-}+2 \mathrm{HCO}_{3}^{-}$

(Reaction 1)

$\mathrm{pSE}=\operatorname{VinAR} \cdot \mathrm{SO}_{4}^{2-} \cdot \frac{\mathrm{M}_{\mathrm{HS}-}}{\mathrm{M}_{\mathrm{SO} 4}}$

\subsection{Bioenergy recovery through biodigestion}

The recovery of bioenergy through biodigestion was considered for the hydrogen- (biogas- $\mathrm{H}_{2}$ ) and methane-rich (biogas- $\mathrm{CH}_{4}$ ) biogas streams obtained from the bioconversion of vinasse during the acidogenic and methanogenic (single-phase or combined) steps, respectively. Eqs. (10) and (11) present the calculations for the potential hydrogen production rate (pHPR) and potential methane production rate (pMPR), which were obtained in terms of $\mathrm{Nm}^{3}-\mathrm{H}_{2} \mathrm{~h}^{-1}$ and $\mathrm{Nm}^{3}-$
$\mathrm{CH}_{4} \mathrm{~h}^{-1}$, respectively. The terms VFR, $\mathrm{COD}_{\text {vinasse, }} \mathrm{HY}, \mathrm{ER}_{\mathrm{COD}}$, and MY correspond to the vinasse flow rate (VFR, $\mathrm{m}^{3} \mathrm{~h}^{-1}$ ), the COD of vinasse $\left(\mathrm{kg} \mathrm{m}^{-3}\right)$, the hydrogen yield $\left(\mathrm{Nm}^{3}-\mathrm{H}_{2} \mathrm{~kg}^{-1} \mathrm{COD}_{\text {influent }}\right)$, the COD removal efficiency in the methanogenic step (dimensionless), and the methane yield $\left(\mathrm{Nm}^{3}-\mathrm{CH}_{4} \mathrm{~kg}^{-1} \mathrm{COD}_{\text {removed }}\right.$ ). For pHPR and pMPR (single-phase), the term $\mathrm{COD}_{\text {vinasse }}$ corresponds to the COD values measured in raw vinasse (Section 2.1). For pMPR (two-phase), the term $\mathrm{COD}_{\text {vinasse }}$ corresponds to the $\mathrm{COD}$ value estimated for acidified vinasse, assuming a $20 \%$ previous reduction in the COD of vinasse during the acidogenic phase (Table 1). The terms HY, MY, and $\mathrm{ER}_{\mathrm{COD}}$ were obtained from Ferraz Jr. et al. (2016), Fuess et al. (2016), and Fuess et al. (2017a) (Table 1), considering optimized thermophilic $\left(55^{\circ} \mathrm{C}\right)$ AD systems applied to sugarcane vinasse.

$$
\begin{aligned}
& \mathrm{pHPR}=\mathrm{VFR} \cdot \mathrm{COD}_{\text {vinasse }} \cdot \mathrm{HY} \\
& \mathrm{pMPR}=\mathrm{VFR} \cdot \mathrm{COD}_{\text {vinasse }} \cdot \mathrm{ER}_{\mathrm{COD}} \cdot \mathrm{MY}
\end{aligned}
$$

The energetic potential (EP) of the biogas- $\mathrm{H}_{2}$ and biogas- $\mathrm{CH}_{4}$ streams was calculated according to Eqs. (12) and (13), respectively. In this case, the production of electricity and the recovery of thermal energy were considered, regarding the application of internal combustion engines (ICE; biogas- $\mathrm{CH}_{4}$ ) and fuel cells (biogas- $\mathrm{H}_{2}$ ). In Eqs. (12) and (13), the terms $\mathrm{EP}, \mathrm{LHV}_{\mathrm{H} 2}, \mathrm{LHV}_{\mathrm{CH} 4}$, and $\eta$ correspond to the energetic potential of biogas (MW), the lower heating values of hydrogen and methane $\left(\mathrm{MJ} \mathrm{Nm}^{-3}\right)$, and the energy conversion factors of the prime movers (dimensionless). The electric conversion factors of 0.43 and 0.40 were considered for the ICE and fuel cell, respectively, whereas the values of 0.51 (ICE) and 0.30 (fuel cell) were considered for the recovery of thermal energy (Table 1 ).

$$
\begin{aligned}
& \mathrm{EP}=\frac{\mathrm{pHPR} \cdot \mathrm{LHV}_{\mathrm{H} 2} \cdot \eta}{3600} \\
& \mathrm{EP}=\frac{\mathrm{pMPR} \cdot \mathrm{LHV}_{\mathrm{CH} 4} \cdot \eta}{3600}
\end{aligned}
$$




\section{Results and discussion}

\subsection{Seasonal characterization of sugarcane vinasse}

Compositional aspects from sugarcane vinasse throughout the year 2014 are depicted in Figs. 1 to 3, including the overall characterization of the organic and inorganic fractions (Fig. 1a-c), the breakdown of the soluble organic fraction (Fig. 2a-b), and the characterization of trace metal levels (Fig. 3). An overall analysis indicates a slight reduction in the biodegradability of vinasse throughout the harvest, based on the decreasing values obtained for the BOD/T-COD ratio (0.54 to 0.43 ; Fig. 1a). Conversely, the S-COD/T-COD ratio remained approximately constant throughout the harvest $(0.73-0.81$; Fig. $1 \mathrm{a})$, indicating the predominant contribution of soluble compounds to the organic fraction of vinasse.

Although T-COD values were usually above $30 \mathrm{~g} \mathrm{~L}^{-1}$ (Fig. 1a), as expected for vinasses from annexed sugarcane-based biorefineries (Fuess and Garcia, 2014), two events in which the organic content of vinasse showed a marked decrease were observed, specifically in July and November. In these cases, the T-COD reached values below $25 \mathrm{~g} \mathrm{~L}^{-1}$ (Fig. 1a), characterizing an organic content similar to that in vinasses from autonomous distilleries, i.e., biorefineries based only on the production of ethanol. In fact, these patterns resulted from alterations in the production profile of the biorefinery, based on the allocation of larger proportions of the TRS (up to 70\%) for ethanol production due to certain market factors, such as an increasing demand for ethanol from May 2014 onwards and decreasing prices of sugar in the international market. In terms of vinasse composition, higher ethanol production (or lower sugar production) levels directly imply the use of lower proportions of molasses in the preparation of the fermentable broth (Fuess et al., 2017c), which further leads to less concentrated vinasses.

The concentration profiles obtained for major (Fig. 1b) and secondary (Fig. 1c) nutrients, primarily $\mathrm{K} \mathrm{SO}_{4}^{2-}$, and $\mathrm{Ca}$, corroborate the aforementioned pattern, based on decreasing levels in the respective months. The diversion of higher TRS proportions to ethanol production naturally increased the generation rates of vinasse within the biorefinery, so that an ethanol yield of $65.2 \mathrm{~L} \mathrm{TC}^{-1}$ ( $70 \%$ of the TRS directed to ethanol production) and a subsequent vinasse flow rate of $1203.09 \mathrm{~m}^{3} \mathrm{~h}^{-1}$ were considered in the estimates for July and November. The estimated ethanol yield reaches an intermediate position between reference values of $82.9 \mathrm{~L} \mathrm{TC}^{-1}$ and $53.4 \mathrm{~L} \mathrm{TC}^{-1}$, which correspond to expected levels when 100\% (autonomous distillery) and $50 \%$ (annexed distillery) of the TRS are directed to ethanol production, respectively. Overall, the calculated ethanol yield for July and November was $22.1 \%$ higher than the reference input value indicated in Table 1.

The breakdown of the soluble organic fraction indicated an increase in the remaining ethanol fractions in vinasse in July and August 2014 (1.1-1.6 $\mathrm{g} \mathrm{L}^{-1}$; Fig. 2a), which could also be associated with the increasing ethanol production levels in the biorefinery in the considered period. Although not measured in this study, the concurrent increase in the production of fusel oil, i.e., high-molecular-weight compounds (primarily higher chain alcohols), could potentially explain these results, as ethanol distillation is negatively impacted by azeotropes formed by fusel oil components and water (Mayer et al., 2015). High levels of iso-butyric, lactic, succinic, and malic acids were measured in the vinasse samples throughout the harvest (Fig. 2a), reaching similar values to those reported by Santos et al. (2014a, 2014b).

The presence of lactic acid in vinasse usually results from the contamination of the fermentation vessels by lactic acid bacteria, as these microorganisms are characterized as the most acid-tolerant bacteria (Siegumfeldt et al., 2000); therefore, they survive the high levels of sulfuric acid $\left(\mathrm{H}_{2} \mathrm{SO}_{4}\right)$ applied to the vessels (up to $5 \mathrm{~kg} \mathrm{~m}^{-3}$ ethanol; Morais et al., 2016) in the prevention of microbial contamination. The accumulation of succinic and malic acids primarily results from parallel metabolic pathways performed by yeast (Jayaram et al., 2014; Lupiañez et al., 1974; Thoukis et al., 1965; Zelle et al., 2008).
The measured soluble compounds in vinasse usually accounted for over $80 \%$ of the S-COD (Fig. $2 \mathrm{~b}$ ), and the unrecovered organic fractions were most likely composed of specific compounds, such as glycerol and melanoidins. In particular, glycerol is also a relevant constituent of vinasse, with reported concentrations ranging between 2.8 and $5.9 \mathrm{~g} \mathrm{~L}^{-1}$ (Bonini, 2012; Dowd et al., 1994; Pereira, 1991). Glycerol is the primary byproduct released by yeast under stress conditions (Melo, 2006; Navarro et al., 2000), so that up to 9\% of the TRS available to yeast may be converted into this metabolite (Bonini, 2012).

Regarding the inorganic fraction, $\mathrm{K}_{2} \mathrm{SO}_{4}^{2-}$, $\mathrm{Ca}$, and $\mathrm{Mg}$ were the primary constituents measured in vinasse throughout the harvest (Fig. 1b-c), with concentrations ranging from 2720 to $4175 \mathrm{mg} \mathrm{L}^{-1}$, 1044 to $2079 \mathrm{mg} \mathrm{L}^{-1}, 812$ to $2280 \mathrm{mg} \mathrm{L}^{-1}$, and 164 to $348 \mathrm{mg} \mathrm{L}^{-1}$, respectively. In particular, lower $\mathrm{SO}_{4}^{2-}$ concentrations (1044-1164 mg L ${ }^{-1}$, July and August; Fig. 1b) were associated with higher ethanol production levels, which also resulted from lower proportions of molasses in the fermentable broth. Molasses comprises the residual stream from sugar production, presenting high levels of remaining sulfur compounds from specific processing steps, therefore contributing to the accumulation of $\mathrm{SO}_{4}^{2-}$ in vinasse. The $\mathrm{SO}_{4}^{2-}$ concentration profile further indicated an increasing trend by the end of the harvest (up to $2079 \mathrm{mg} \mathrm{L}^{-1}$; Fig. 1b), even when an additional enhancement in ethanol production (i.e., lower inputs of molasses and sulfur compounds from sugar production) was observed (November 2014). This pattern suggests that the accumulation of $\mathrm{SO}_{4}^{2-}$ in vinasse resulted from increasing doses of $\mathrm{H}_{2} \mathrm{SO}_{4}$ in the fermentation vessels, which directly impacts the bioenergy recovery potential from vinasse (see Section 3.3). The use of $\mathrm{H}_{2} \mathrm{SO}_{4}$ aims to prevent both the microbial contamination and the flocculation of yeasts throughout the harvest as an approach to maintain high ethanol productivities.

The incorporation of $\mathrm{K}$ into vinasse results from the juice extraction step in which the $\mathrm{K}$ from plant tissues is solubilized into the liquid phase. Similarly, Mg is also incorporated from plant tissues. The use of molasses as a carbon source in fermentation also tends to increase both the $\mathrm{K}$ and $\mathrm{Mg}$ levels in vinasse, as salts are concentrated during the steps of evaporation and crystallization in sugar production. In general, the K concentrations measured in vinasse throughout the harvest (Fig. 1b) were similar to the values previously reported in vinasses from annexed sugarcane biorefineries: $3147 \mathrm{mg} \mathrm{L}^{-1}$ (Siqueira et al., 2013), 3800-4500 $\mathrm{mg} \mathrm{L}^{-1}$ (Santos et al., 2014b), and $4500 \mathrm{mg} \mathrm{L}^{-1}$ (Reis et al., 2015), except when lower proportions of molasses were fermented (July and November). In these cases, the K concentrations (2500-2700 $\mathrm{mg} \mathrm{L}^{-1}$; Fig. 1b) were similar to the values measured in vinasses from autonomous ethanol plants, with a reference value of $2300 \mathrm{mg} \mathrm{L}^{-1}$ (Ferreira et al., 2011).

The Ca concentrations measured in vinasse $\left(>1000 \mathrm{mg} \mathrm{L}^{-1}\right.$; Fig. 1c) were usually above the values found in sugarcane vinasses elsewhere: 698-757 $\mathrm{mg} \mathrm{L}^{-1}$ (Santos et al., 2014b) and $757 \mathrm{mg} \mathrm{L}^{-1}$ (Reis et al., 2015). This pattern probably results from the use of Ca oxides and hydroxides in the treatment of juice, so that the enormous processing capacity of the referred biorefinery $\left(9.3 \times 10^{6} \mathrm{TC}\right.$ harvest $\left.^{-1}\right)$ favored the accumulation of higher Ca levels in vinasse. An enhanced incorporation of Ca by sugarcane from the soil may also have contributed to the observed pattern. In particular, the effects from the incorporation of soil elements on the vinasse composition should be more evident for trace metals (Fig. 3), although the results indicated minimal variations for the analyzed elements throughout the harvest, especially for Co (0.14-0.26 mg L $\left.{ }^{-1}\right)$, Ni (0.12-0.28 $\left.\mathrm{mg} \mathrm{L}^{-1}\right)$, Cd (0.05-0.18 $\left.\mathrm{mg} \mathrm{L}^{-1}\right)$, and $\mathrm{Mn}\left(2.0-4.3 \mathrm{mg} \mathrm{L}^{-1}\right)$. The high Fe concentrations (compared with the other trace elements) determined in vinasse $\left(8.84-23.12 \mathrm{mg} \mathrm{L}^{-1}\right.$; Fig. 3) most likely resulted from the absorption of Fe ions in the soil; these ions are abundantly released from Fe-rich minerals due to weathering under tropical conditions (Fuess et al., 2017c). Similar patterns should be observed for aluminum levels in sugarcane vinasse, although no measurements have been performed for this metal. 

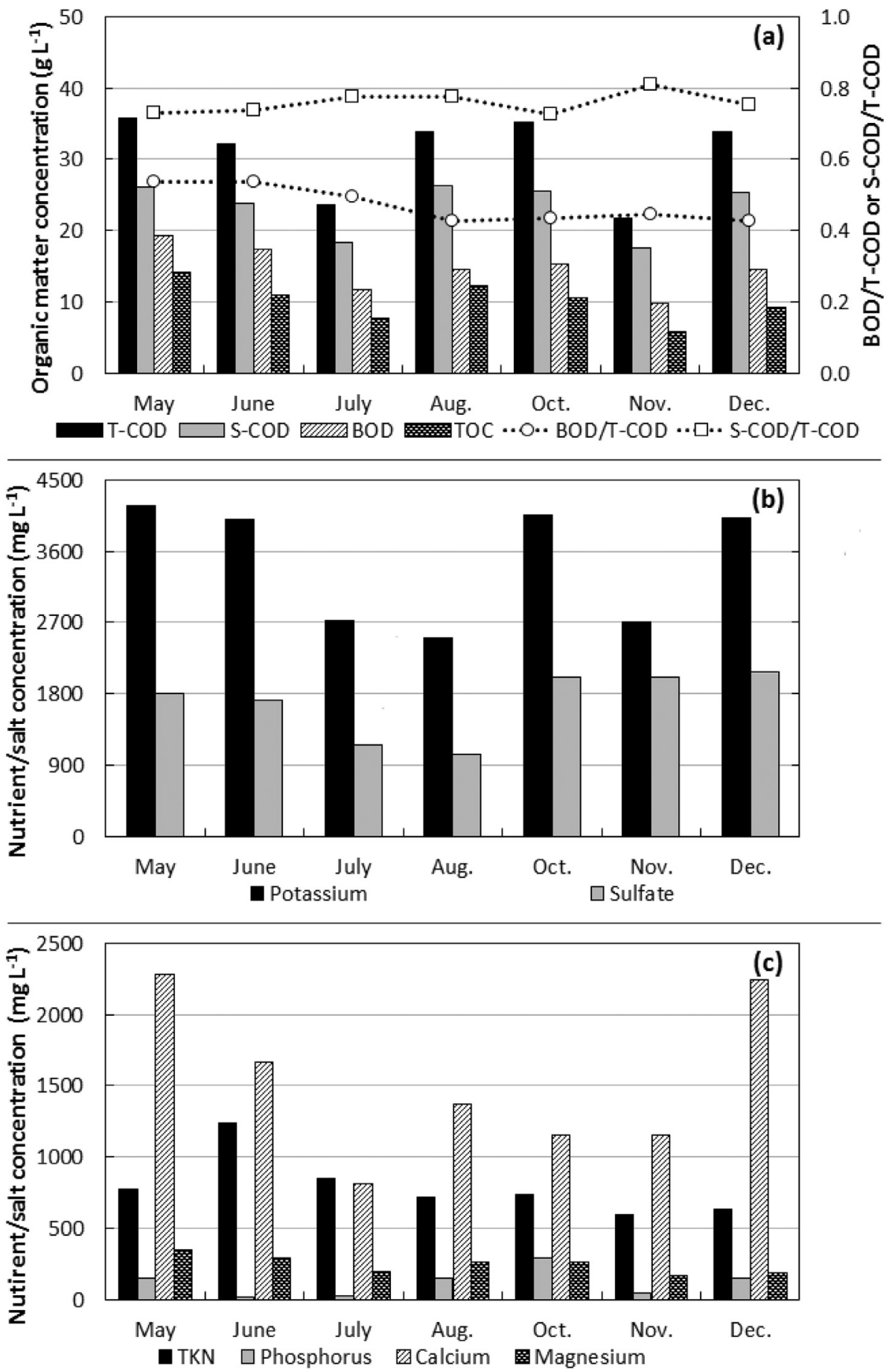

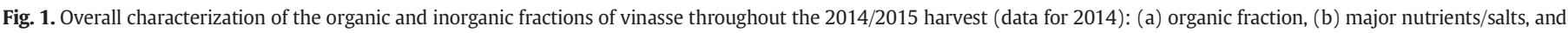
(c) secondary nutrients/salts.

\subsection{Environmental aspects of fertirrigation}

The application rates estimated from the K content measured in sugarcane vinasse throughout the harvest are depicted in Fig. 4, with values ranging from 120 to $201 \mathrm{~m}^{3} \mathrm{ha}^{-1}$ and 89 to $148 \mathrm{~m}^{3} \mathrm{ha}^{-1}$ for nonfertilized/fertirrigated and continuously fertirrigated soils, respectively. Although these values are in accordance with the application rates commonly used in the Brazilian sucro-alcohol industry - 115-234 $\mathrm{m}^{3} \mathrm{ha}^{-1}$ (Tasso Jr. et al., 2007) and $150 \mathrm{~m}^{3} \mathrm{ha}^{-1}$ (Silva et al., 2014; Zolin et al., 2011), the corresponding inputs of $\mathrm{K}$ into the soils would reach 502 and $371 \mathrm{~kg} \mathrm{ha}^{-1}$ (602 and $445 \mathrm{~kg}-\mathrm{K}_{2} \mathrm{O} \mathrm{ha}{ }^{-1}$ ) in vinasse-free and continuously fertirrigated areas, respectively. These values are approximately 2.7 - and 2.0 -fold higher, respectively, than the $\mathrm{K}$ requirements of most crops (185 $\mathrm{kg} \mathrm{ha}^{-1}$; WHO, 2006), suggesting the saturation of soils with K. Studies on the interaction of $\mathrm{K}$ ions and soil structures are inconclusive (Arienzo et al., 2012; Fuess and Garcia, 2014); however, the accumulation of $\mathrm{K}$ in soils may lead to relevant negative impacts, such as essential nutrient losses ( $\mathrm{Ca}$ and Mg; Gariglio, 2008), an increase in soil erodibility coupled with the anticipation of runoff (Auerswald et al., 1996), and hydraulic conductivity losses due to the dispersion of fine particles (Arienzo et al., 2009, 2012). 

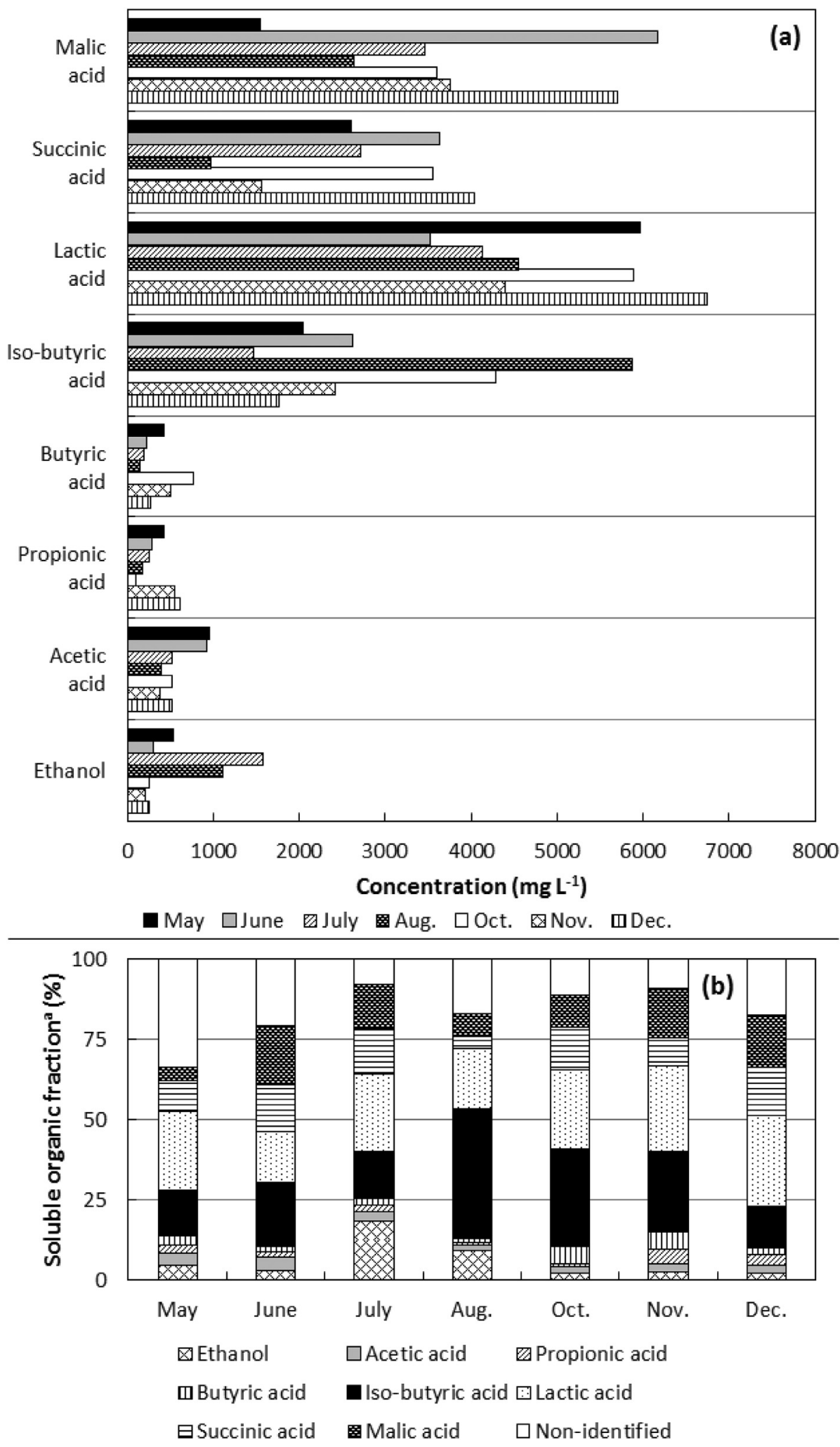

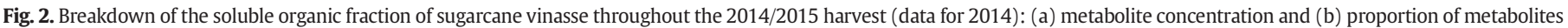

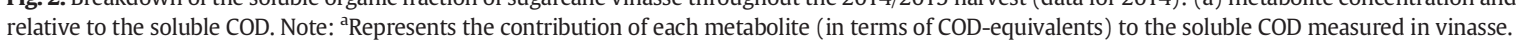

The definition of an economic radius for the application of vinasse, which characterizes a typical practice in the Brazilian sucro-alcohol industry, tends to increase the negative impacts from the accumulation of salts in soils. The economic radius indicates a distance relative to the distillery, beyond which the transportation of vinasse is economically unfeasible, so that fertirrigation becomes more expensive than the cost of mineral fertilization (Fuess et al., 2017c). In practical terms, the inputs of $\mathrm{K}$ (and other compounds) into the soils are much higher than the values calculated from the normative instruction (Section 2.3; CETESB, 2015), rendering the agricultural areas closer to the biorefineries more susceptible to the negative impacts from fertirrigation. 


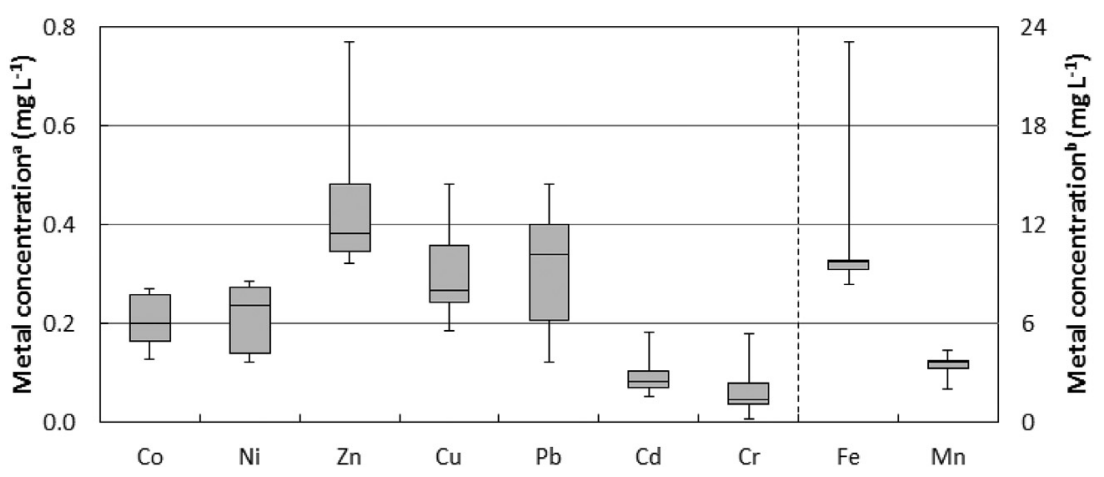

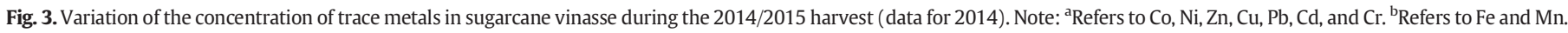

With respect to the inputs of organic matter, the estimated $\mathrm{AOL}_{\text {soil }}$ could reach over 2.5 and 2.0 ton-BOD ha ${ }^{-1}$ in the harvest in nonfertilized/fertirrigated (Fig. 4a) and fertirrigated (Fig. 4b) soils, respectively. This enormous amount of easily degradable organic matter continuously provided to the soil microbiota could trigger numerous biological processes, especially the uncontrolled release of greenhouse gases (GHG). The application of organic overloads into soils tends to stimulate the microbial activity, which promptly depletes oxygen levels and generates conditions of anaerobiosis (Fuess and Garcia, 2014). Moreover, the high amounts of nitrogen (TKN $=598-1243 \mathrm{mg} \mathrm{L}^{-1}$ ) present in vinasse, primarily organic nitrogen, may be converted into nitrogen oxides, such as nitrous oxide $\left(\mathrm{N}_{2} \mathrm{O}\right)$, as a result of incomplete denitrification pathways (Moraes et al., 2014; Oliveira et al., 2013), greatly increasing the GHG emissions in sugarcane fields. The global warming potential of $\mathrm{N}_{2} \mathrm{O}$ is 310-fold higher than that of carbon dioxide, considering a time horizon of 100 years (United Nations, 2016). The uncontrolled conversion of organic matter also implies considerable bioenergy losses, using the potential of AD systems for the production of biogas as a reference (see Section 3.3).

Comparatively, the pollution load associated with the application of raw vinasse to soils would be equivalent to that for population densities over 159 and 117 inhab ha ${ }^{-1}$ in non-fertirrigated (Fig. 4a) and continuously fertirrigated (Fig. 4b) areas, respectively, peaking at 257 inhab ha ${ }^{-1}$ in vinasse-free soils (Fig. 4a). These values are 1.7-3.7-fold higher than the pollution load for the largest population densities observed in Brazilian capital cities, such as Fortaleza
(78 inhab ha ${ }^{-1}$ ), São Paulo (74 inhab ha ${ }^{-1}$ ), Belo Horizonte (72 inhab ha ${ }^{-1}$ ), and Recife (70 inhab ha ${ }^{-1}$ ) (IBGE, 2016).

The application of biodigestion as the core treatment process for sugarcane vinasse in biorefineries could lead to more favorable scenarios in terms of the $\mathrm{AOL}_{\text {soil }}$ (Fig. 4c-f), as expected; however, significantly distinct patterns would result from the implementation of single- and two-phase schemes. The application of single-phase biodigestion would result in polluting loads (1.2-2.7 ton-COD ha ${ }^{-1}$; Fig. 4e-f) equivalent to that generated by populations ranging from 52 to 118 inhab ha ${ }^{-1}$, regardless of the soil type (Fig. 4e-f), whereas the maximum equivalent population estimated for biodigested vinasse from two-phase AD schemes is 52 inhab ha ${ }^{-1}\left(\mathrm{AOL}_{\text {soil }}=1.2\right.$ ton-COD ha ${ }^{-1}$; Fig. 4c). The controlled input of organic matter into the soil triggers numerous beneficial effects, such as the formation of stable soil aggregates and an increase in the moisture and CEC of the terrain (Fuess and Garcia, 2014; Tejada et al., 2007).

The marked discrepancy when comparing vinasses from single- and two-phase AD systems results from the more favorable conditions observed for the bioconversion of organic matter in systems with phase separation, as the pre-acidification of the wastewater enhances the biodegradability of organic compounds, provides higher performance stability to the reactors, and enhances the bioenergy extraction via methane production (see Section 3.3) (Ferraz Jr. et al., 2016; Fuess et al., 2017a; Ke et al., 2005). Regardless of phase separation, the biodigestion of vinasse could avoid the $\mathrm{H}_{2} \mathrm{~S}$ emissions of up to $126 \mathrm{~kg}$ per hectare (Fig. 5a) in non-fertilized/fertirrigated soils, thus
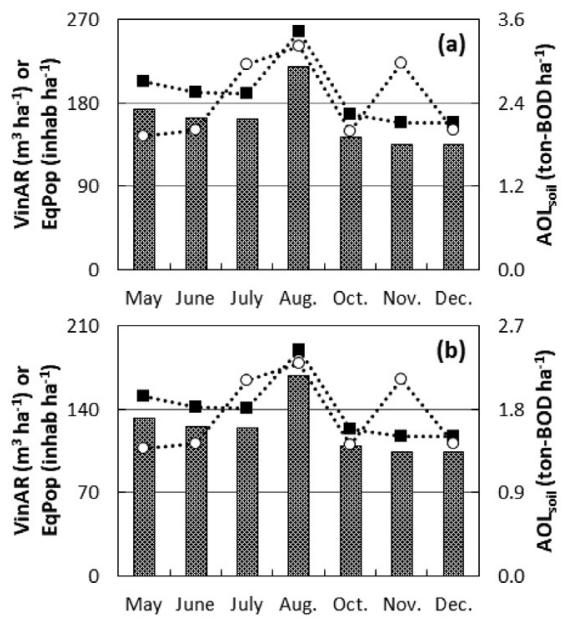
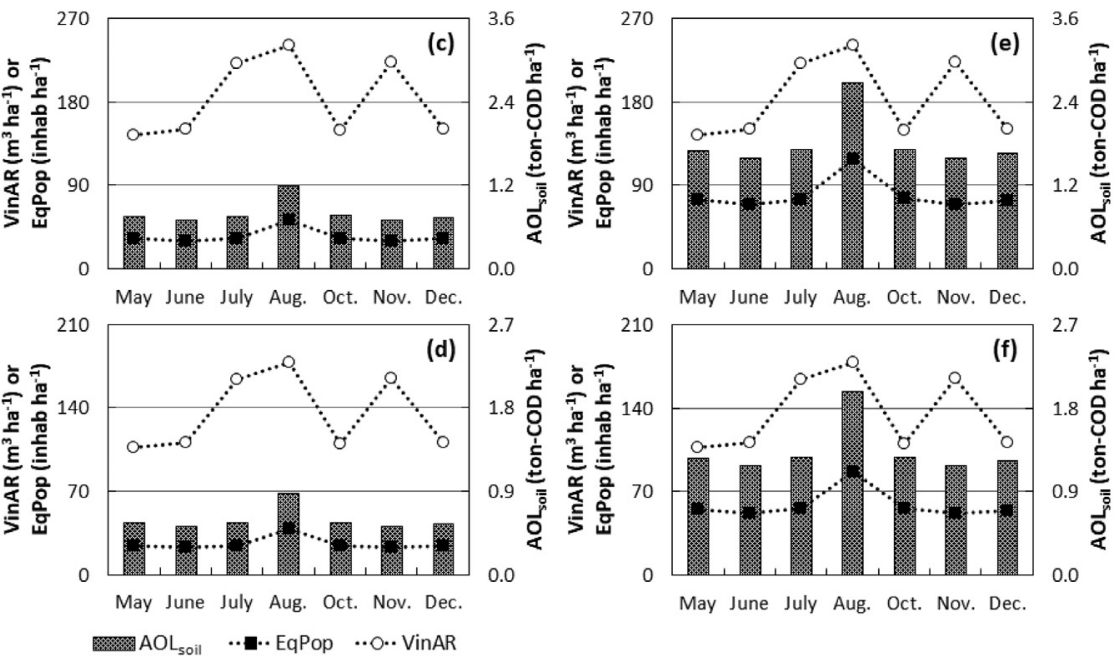

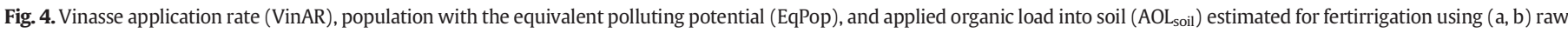

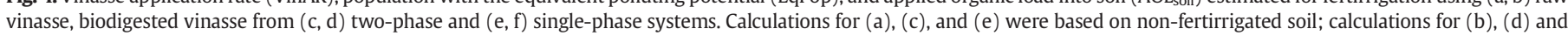
(f) were based on fertirrigated soil (Table 1 ). 
eliminating problems associated with the release of malodors. Furthermore, the eventual implementation of unities for the removal of $\mathrm{H}_{2} \mathrm{~S}$ from biodigested vinasse and biogas could allow the recovery of elemental sulfur $\left(S^{8} ; 133-311 \mathrm{~kg} \mathrm{~m}^{-3}\right.$ vinasse; Fig. 5a), diversifying the recovery of resources in the biorefinery. In this case, the process of microaeration was assumed for the removal of $\mathrm{H}_{2} \mathrm{~S}$, as proposed in Reaction (2) by Muñoz et al. (2015). The molar mass of $S^{8}$ was set to $256 \mathrm{~g} \mathrm{~mol}^{-1}$ (Jespersen, 2007).

$\mathrm{H}_{2} \mathrm{~S}+0.5 \mathrm{O}_{2} \rightarrow \mathrm{S}^{8}+\mathrm{H}_{2} \mathrm{O}$

(Reaction 2)

Despite the reduced polluting organic load of biodigested vinasse, special attention should be given to the role of $\mathrm{Na}$ in the areas subsequently fertirrigated with the effluents from the anaerobic plant. Sugarcane vinasse naturally contains low levels of $\mathrm{Na}\left(16.8-70.0 \mathrm{mg} \mathrm{L}^{-1}\right.$; data for raw vinasse), primarily due to the low Na content in the tropical soils used in sugarcane cultivation; these soils are predominately characterized by Al- and Fe-rich minerals (e.g., kaolinite, gibbsite and hematite; Costa et al., 2002). However, the application of high doses of Na-based alkalizing compounds, such as $\mathrm{NaOH}$ and $\mathrm{NaHCO}_{3}$, in biodigestion systems may significantly increase Na concentrations in vinasse, which may trigger negative impacts in soils due to sodification. Sodification represents a specific type of soil salinization in which $\mathrm{Na}^{+}$ions act as dispersive agents by destabilizing soil aggregates, further clogging soil pores and decreasing the hydraulic conductivity of the terrain (Tejada and Gonzalez, 2006; WHO, 2006).

SAR values estimated for raw vinasse (0.10-0.51; Fig. 5b) indicated a low potential for soil sodification, as expected for sugarcane vinasses (Fuess and Garcia, 2014; Fuess et al., 2017c). Conversely, the values estimated for the SAR in biodigested vinasse reached levels above 15 and 20 for streams resulting from two- and single-phase AD systems, respectively (Fig. 5b). These values are considerably higher than the reference SAR, above which medium-to-high Na-hazard risks may occur in soils (10; Richards, 1954), especially for biodigested vinasses from single-phase systems. In these cases, biodigested vinasse from alkalizing agent-added digesters should not be considered a suitable effluent for fertirrigation, despite the reduced polluting organic load. In particular, these results complement some of the drawbacks previously associated with the application of high doses of alkalizing compounds in full-scale $\mathrm{AD}$ plants, such as the economic unfeasibility and the intrinsic environmental limitations of the production chains of $\mathrm{NaOH}$ and $\mathrm{NaHCO}_{3}$ (high fossil energy demand) (Fuess et al., 2017b, 2018). Moreover, the results reinforce the need for optimizing the use of alkalizing compounds in $\mathrm{AD}$ systems applied to vinasse, so that the use of low $\mathrm{NaOH}$ doses (e.g., $4 \mathrm{~g} \mathrm{NaOH} \mathrm{kg}^{-1} \mathrm{COD}$, as proposed by Souza et al., 1992) would lead to negligible alterations in the SAR of vinasse. In this case, the SAR values would only vary between 0.54 and 0.88 , indicating a suitable effluent for soil application.

Using alternative alkalizing agents, such as urea (Boncz et al., 2012; Janke et al., 2016) could also provide favorable scenarios regarding the further land application of biodigested vinasse. Urea decomposition releases ammonia, which could increase the $\mathrm{N}$-content in vinasse and reduce costs with the supplementation of mineral fertilizers. On the other hand, high ammonia doses could inhibit methane production, especially at $\mathrm{pH}$ values above 7.5 due to the predominance of the free form $\left(\mathrm{NH}_{3}\right)$ (Boncz et al., 2012), negatively impacting the primary target of AD, i.e., bioenergy recovery. Regardless of the type of alkalizing agent, effluent recirculation tends to be the best approach to reach an effective and low-cost alkalizination strategy in full-scale systems treating vinasse (Fuess et al., 2017b). In this case, recycling the alkalinity produce in loco, i.e., resulting from acetoclastic methane production (Reaction (3); Fuess et al., 2017b), may eliminate external inputs of chemicals to control the buffer capacity of AD systems (Nandy et al., 2002). Nevertheless, providing alkali compounds during the start-up phase of highrate anaerobic reactors tends to be an important approach to maximize energy extraction from vinasse (Fuess et al., 2017b, 2018). Therefore,
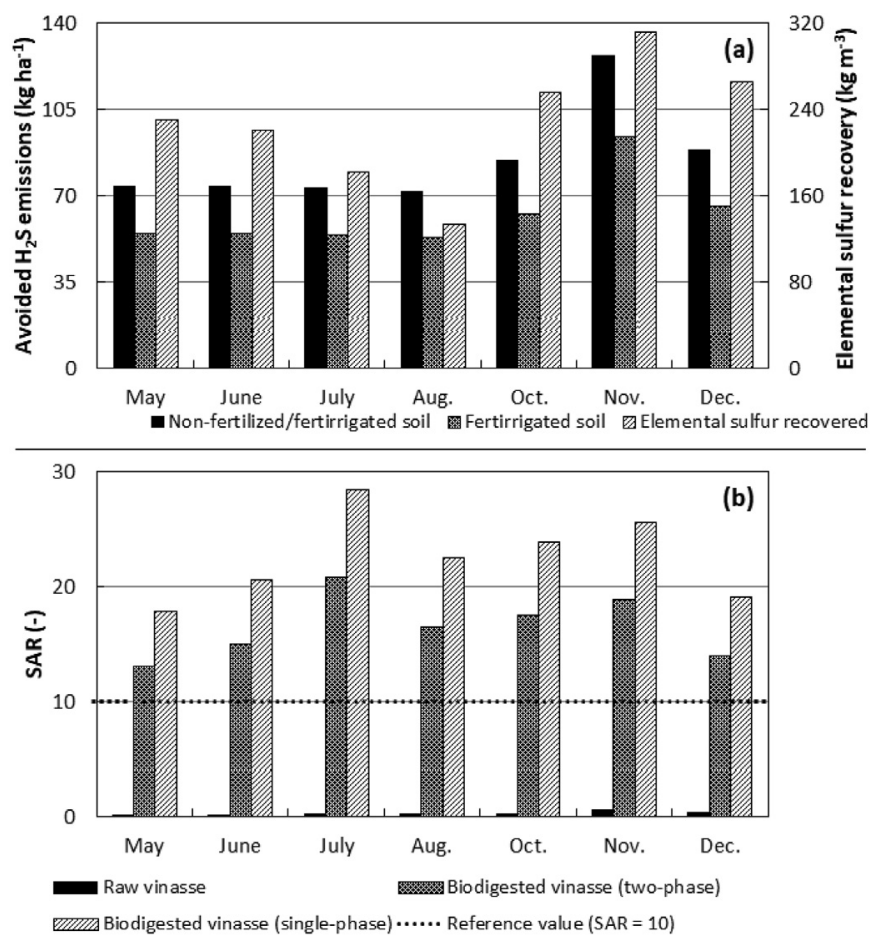

Fig. 5. Implications of the application of biodigestion to sugarcane vinasse: (a) theoretical values of the avoided sulfide emissions and potential elemental sulfur recovery, and (b) effects on the sodium adsorption ratio (SAR) due to using $\mathrm{NaHCO}_{3}$ as an alkalizing compound. Note: Reference value for the SAR (10) obtained from Richards (1954).

understanding the fate of Na characterizes a relevant aspect of implementing $\mathrm{AD}$ in sugarcane biorefineries.

$\mathrm{CH}_{3} \mathrm{COO}^{-}+\mathrm{H}_{2} \mathrm{O} \rightarrow \mathrm{HCO}_{3}^{-}+\mathrm{CH}_{4}$

(Reaction 3)

\subsection{Bioenergy recovery through biodigestion}

Estimates on the production of hydrogen and methane as well as on the recovery of bioenergy from sugarcane vinasse are depicted in Fig. 6. Methane production would be approximately constant throughout the harvest, with values ranging between 5053 and $6277 \mathrm{Nm}^{3} \mathrm{~h}^{-1}$ (5834 $\pm 441 \mathrm{Nm}^{3} \mathrm{~h}^{-1}$ ) and between 4033 and $5010 \mathrm{Nm}^{3} \mathrm{~h}^{-1}$ (4656 \pm $352 \mathrm{Nm}^{3} \mathrm{~h}^{-1}$ ) for two- and single-phase AD systems, respectively, excluding data for November (Fig. 6a-b). The pMPR for the two-phase AD system would be approximately $20 \%$ higher than that for the single-phase system, based on the advantages of phase separation in terms of the higher biodegradability of vinasse and operational stability of the reactors (Ferraz Jr. et al., 2016; Fuess et al., 2017a). The lower pMPR estimated for November, regardless of phase separation, resulted from two factors: the lower organic content of vinasse, given the lower inputs of molasses in the fermentation broth when ethanol production was increased (see Section 3.1), and the negative effects from higher sulfate concentrations in vinasse (Fig. 1b). In particular, the lower organic content of vinasse should be offset by the higher vinasse flow rate during this period, as observed in the estimate for July; therefore, the accumulation of sulfate was the determining factor for the marked reduction in methane production.

The COD/sulfate levels reached critical levels in November ( 8.7 and 10.8 for two- and single-phase systems, respectively), which could markedly impact the methanogenic activity of the reactors due to the concurrent activity of sulfate-reducing bacteria (Eq. (1)). In this study, the reference values used to predict the impacts of sulfidogenesis were obtained from Kiyuna et al. (2017), who reported performance losses, in terms of methane production, of approximately 16\% and 35\% 
for biodigestion systems applied to sugarcane vinasse with COD/sulfate ratios of 10.0 and 7.5 , respectively. The discrepancy regarding the COD/ sulfate values in the raw (10.8-32.4; Fig. 6b) and acidified (8.7-25.9; Fig. 6a) vinasse resulted from the negligible sulfate removal rates considered for the acidogenic phase, as reported by Fuess et al. (2016). Consequently, the slightly higher pMPR estimated for the single-phase AD scheme (3115 vs. $3020 \mathrm{Nm}^{3} \mathrm{~h}^{-1}$; Fig. 6a-b) in November resulted from a more relevant impact of sulfidogenesis in the methanogenic reactor of the two-phase system, given the previous removal of organic matter from vinasse during acidogenesis (20\%, Table 1 ) and the subsequent establishment of lower COD/sulfate ratios.

Similar to methane production, hydrogen production rates would not vary significantly throughout the harvest $\left(620 \pm 66 \mathrm{Nm}^{3} \mathrm{~h}^{-1}\right.$; Fig. 6a) in the acidogenic step of the two-phase AD system. Regarding the recovery of bioenergy, $0.61-0.82 \mathrm{MW}$ and $0.45-0.61 \mathrm{MW}$ of electricity and thermal energy, respectively, could be obtained from hydrogen in the studied biorefinery, based on the use of fuel cells. In terms of electricity production, the values estimated from hydrogen corresponded to $<4 \%$ of the potential estimated for methane (12.9-26.7 MW, two-phase biodigestion; Fig. 6c). The electricity production from methane in single-phase systems (13.3-25.6 MW; Fig. 6d) would be 20\% lower than that from two-phase schemes, except for November, as previously observed for the production of methane.

Regardless of phase separation, the absolute electricity production levels estimated in this study were considerably higher than the values obtained for sugarcane vinasse reported elsewhere: 5.41-5.77 MW (Salomon et al., 2011), 5.02-6.37 MW (Moraes et al., 2014), 6.1-8.3 MW (single-phase) and 7.0-10.8 MW (twophase) (Fuess et al., 2018). This marked discrepancy resulted primarily from the size of the compared plants, as the capacity of the biorefinery considered in this study $\left(9.3 \times 10^{6} \mathrm{TC}^{\text {harvest }}{ }^{-1}\right)$ is 2.3to 4.6 -fold greater than that of the plants considered in the comparative studies (2.0-4.0 × $10^{6} \mathrm{TC}$ harvest $^{-1}$ - Fuess et al., 2018; Moraes et al., 2014). The electric conversion factor considered for the ICE in this study $(0.43$, Table 1$)$ was also higher than the values assumed elsewhere (0.29-0.38 - Moraes et al., 2014; Salomon et al., 2011), which also impacted the obtained results. Nevertheless, in relative terms, the electricity production estimated herein, i.e., 1.4-2.7 and 1.4-2.9 MW per million tons of processed sugarcane (MTC) for single- and two-phase AD approaches, respectively, was similar to that in the reference studies (2.5-3.2 MW MTC ${ }^{-1}$ - Moraes et al., 2014; 1.5-2.7 MW MTC ${ }^{-1}$; Fuess et al., 2018). The electricity production from biogas streams could be enhanced by applying combined cycle power plants, i.e., gas turbines coupled to steam turbines, as proposed by Fuess et al. (2018), based on an electric conversion factor exceeding 0.50 .

An even higher energetic potential could be obtained in terms of thermal energy recovery (15.4-32.1 MW and 15.9-25.6 MW for twoand single-phase systems, respectively; Fig. 6c-d) considering the coupling of heat recovery systems to the ICE $(\eta=0.51$, Table 1$)$, as specified by the manufacturer. Although the heat recovered from biogas has low potential for application in ordinary processes and operations within the biorefinery (Fuess et al., 2018), specifically in terms of steam production, the thermal energy could be directly used to control the temperature of the anaerobic reactors, considering the potentials of thermophilic systems compared with mesophilic schemes (Fuess et al., 2017b; Wilkie et al., 2000). Given that vinasse is released at temperatures above $90^{\circ} \mathrm{C}$, the use of the heat produced from biogas would provide a complimentary temperature control in the reactors. Overall, $>90 \%$ of the gross energetic potential of vinasse could be recovered by combining the production of electricity and thermal energy, directly contributing to an enhanced exploitation of sugarcane.

The electricity obtained from biogas in two-phase AD systems throughout the harvest (12.6 $\mathrm{kWh} \mathrm{TC}^{-1}$, based on an average EP of $23.7 \mathrm{MW}$ ) is comparable to both the electric requirements and the surplus electricity from basic first-generation middle-sized $\left(2.0 \times 10^{6} \mathrm{TC}\right.$ harvest $\left.^{-1}\right)$ Brazilian biorefineries $\left(12.0 \mathrm{kWh} \mathrm{TC}^{-1}\right.$ each; Junqueira et al., 2016). The output electricity from single-phase biodigestion (10.3 $\mathrm{kWh} \mathrm{TC}^{-1}$, based on an average EP of $18.9 \mathrm{MW}$ ) could reach approximately $85 \%$ of the base values. Considering data from the reference biorefinery $\left(9.3 \times 10^{6} \mathrm{TC}\right.$ harvest $\left.^{-1}\right)$, the electricity recovered from biogas (95,394 and 116,803 MWh for single- and twophase AD systems, respectively) would correspond to $31.8-38.9 \%$ of
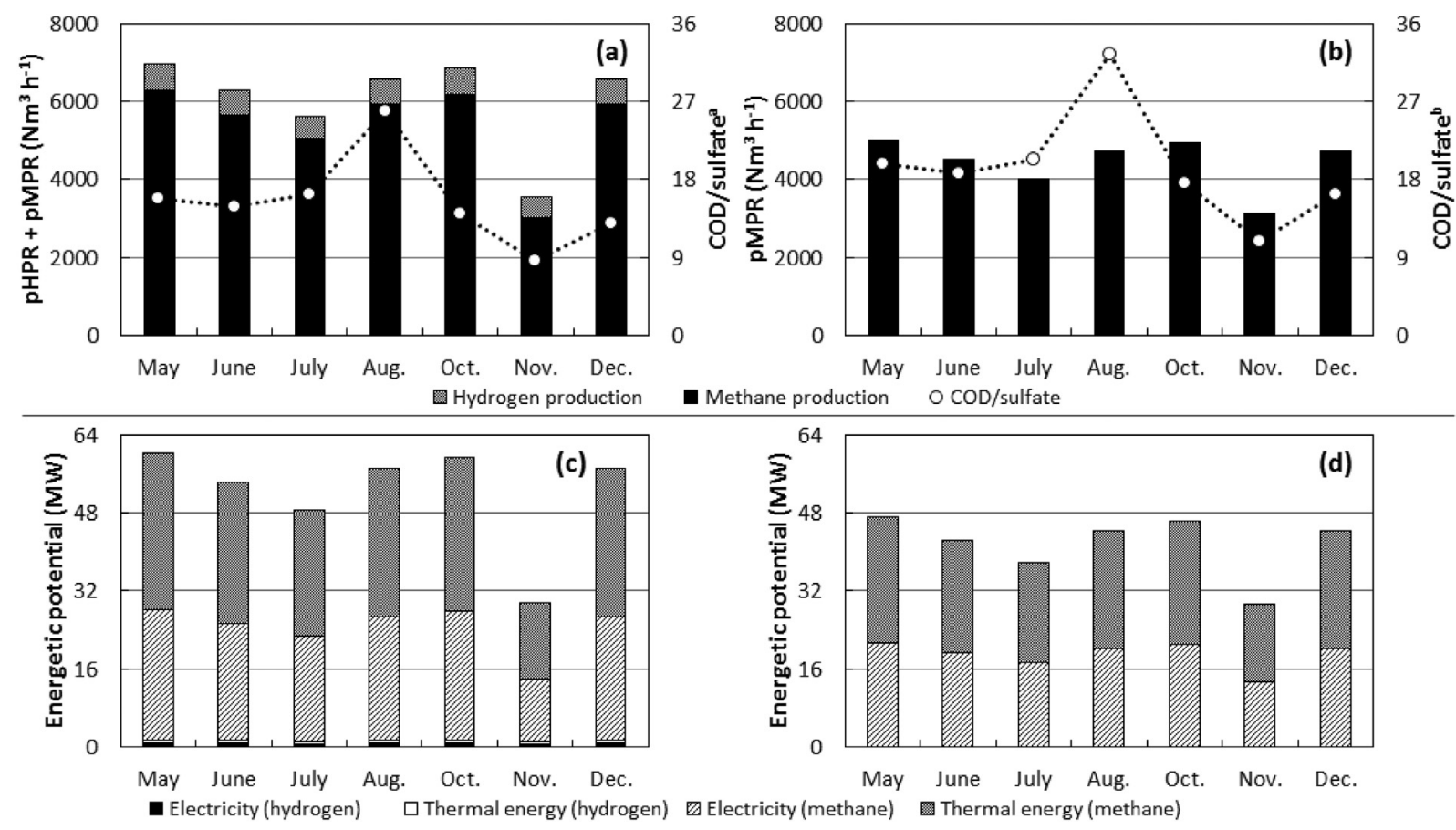

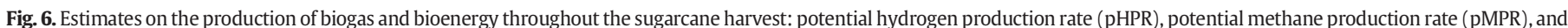

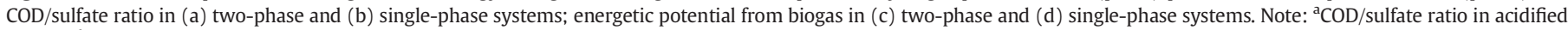

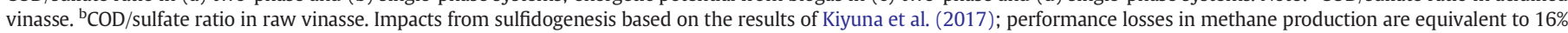
(COD/sulfate 10.0) and 35\% (COD/sulfate < 10.0). 
the surplus thermoelectricity produced from bagasse in the plant $(300,000 \mathrm{MWh})$ in the same year (2014), revealing the application of biodigestion as a direct opportunity for enhancing the profitability of the plant with bioenergy sales. In practical terms, the electricity from biogas could supply populations as high as 250 and 305 thousand inhabitants during the harvest, using a monthly per capita consumption of $0.0543 \mathrm{MWh}_{\text {inhab }}^{-1}$ (assuming a monthly residential energy consumption of $0.163 \mathrm{MWh}$ - EPE, 2014 - and three inhabitants per residence), so that at least seven small-sized cities near the industrial plant could be fully supplied: Guatapará (6966 inhab), Dumont (8143 inhab), Pradópolis (17,377 inhab), Guariba (35,486 inhab), Taquaritinga (53,988 inhab), Jaboticabal (71,662 inhab), and Sertãozinho $(110,074$ inhab) (IBGE, 2016). The electricity from biogas could also fully supply larger cities, such as Araraquara (208,662 inhab) and São Carlos $(221,950$ inhab), or at least $50 \%$ of the consumption in the largest city in the region (Ribeirão Preto, 604,682 inhab; IBGE, 2016).

\section{Conclusions}

The seasonal characterization of sugarcane vinasse enabled an understanding of the potential and limitations of the primary destinations proposed for this residual stream in the Brazilian sucro-alcohol industry. Regarding fertirrigation, the estimated inputs of organic matter into soils in terms of population equivalent were at least 2-fold greater than the most densely populated Brazilian capital cities. The estimated inputs of $\mathrm{K}$ into soils (371-502 $\mathrm{kg} \mathrm{ha}^{-1}$ ) were also considerably higher than the requirements of most crops (185 kg ha $\left.{ }^{-1}\right)$, which could increase the risk of soil salinization. The application of biodigestion, particularly two-phase systems, was shown to be an efficient method to reduce the polluting organic load of vinasse and to eliminate the negative effects from direct sulfide emissions into the environment. However, special attention should be given to the use of high doses of $\mathrm{Na}-$ based alkalizing compounds in AD plants, based on the potential occurrence of soil sodification when applying biodigested vinasse. Na concentrations in biodigested vinasse (from single-phase AD systems) may be 200 -fold higher than that in raw vinasse. Nevertheless, the optimized recovery of bioenergy through biogas (13.3-26.7 MW as electricity) in the reference biorefinery could provide an effective opportunity for enhancing both the economic feasibility of the plant and the bioresource recovery from sugarcane, so that the electricity from biogas (twophase systems) could supply populations exceeding 300 thousand inhabitants. Over $30 \%$ of the surplus electricity produced by the studied biorefinery in the reference period (2014) could be obtained from biogas.

\section{Acknowledgments}

The authors are grateful for the financial support provided by the São Paulo Research Foundation (FAPESP) (grant numbers 2009/15984-0 and 2012/15606-9).

\section{References}

Adorno, M.A.T., Hirasawa, J.S., Varesche, M.B.A., 2014. Development and validation of two methods to quantify volatile acids (C2-C6) by GC/FID: headspace (automatic and manual) and liquid-liquid extraction (LLE). AJAC 5, 406-414.

APHA, AWWA, WEF (Eds.), 2012. Standard methods for the examination of water and wastewater, 22nd ed. APHA, Washington, DC.

Arienzo, M., Christen, E.W., Quayle, W., Kumar, A., 2009. A review of the fate of potassium in the soil-plant system after land application of wastewaters. J. Hazard. Mater. 164, $415-422$.

Arienzo, M., Christen, E.W., Jayawardane, N.S., Quayle, W.C., 2012. The relative effects of sodium and potassium on soil hydraulic conductivity and implications for winery wastewater management. Geoderma 173-174, 303-310.

Auerswald, K., Kainz, M., Angermüller, S., Steindl, H., 1996. Influence of exchangeable potassium on soil erodibility. Soil Use Manag. 12, 117-121.

Boncz, M.A., Formagini, E.L., Santos, L.S., Marques, R.D., Paulo, P.L., 2012. Application of urea dosing for alkalinity supply during anaerobic digestion of vinasse. Water Sci. Technol. 66, 2453-2460.
Bonini, M.A., 2012. Cultivo heterotrófico de Aphanothece microscopica Nägeli e Chlorella vulgaris em diferentes fontes de carbono e em vinhaça [Heterotrophic cultivation of Aphanothece microscopica Nägeli and Chlorella vulgaris in different carbon sources and vinasse] (MSc dissertation). Federal University of São Carlos, Araras, SP, Brazil.

CETESB (Ed.), 2015. Norma P4.231: Vinhaça - Critérios e procedimentos para aplicação no solo agrícola [Stillage - Criteria and procedures for agricultural soil application], 3rd ed. CETESB, São Paulo.

Colin, V.L., Cortes, A.A.J., Aparicio, J.D., Amoroso, M.J., 2016. Potential application of a bioemulsifier-producing actinobacterium for treatment of vinasse. Chemosphere $144,842-847$.

Costa, R.B., Foresti, E., 2014. Strategies for the enrichment of methanotrophic denitrification community. Proceedings of the XI Latin American Workshop and Symposium on Anaerobic Digestion, La Havana, Cuba, pp. 804-811.

Costa, A.C.S., Almeida, V.C., Lenzi, E., Nozaki, J., 2002. Determinação de cobre, alumínio e ferro em solos derivados do basalto através de extrações seqüenciais [Determination of copper, aluminum, and iron in basaltic soils by sequential extractions]. Quim Nova $25,548-552$.

Cruz, L.F.L.S., Duarte, C.G., Malheiros, T.F., Pires, E.C., 2013. Análise da viabilidade técnica, econômica e ambiental das atuais formas de aproveitamento da vinhaça: fertirrigação, concentração e biodigestão [Technical, economic and environmental viability analysis of the current vinasse use: ferti-irrigation, concentration and biodigestion]. 29. RBCIAMB, pp. 111-127.

Dias, M.O.S., Maciel Filho, R., Mantelatto, P.E., Cavalett, O., Rossell, C.E.V., Bonomi, A., Leal, M.R.L.V., 2015. Sugarcane processing for ethanol and sugar in Brazil. Environ. Dev. 15, 35-51.

Dowd, M.K., Johansen, S.L., Cantarella, L., Reilly, P.J., 1994. Low molecular weight organic composition of ethanol stillage from sugarcane molasses, citrus waste, and sweet whey. J. Agric. Food Chem. 42, 283-288.

EPA, 1993. Method 351.2: Determination of total Kjeldahl nitrogen by semi-automated colorimetry. Revision 2.0. US Environmental Protection Agency, Cincinnati, OH.

EPA, 1994. Method 200.2: Sample preparation procedure for spectrochemical determination of total recoverable elements. Revision 2.8. US Environmental Protection Agency, Cincinnati, $\mathrm{OH}$.

EPA, 1998. Method 200.9: Trace Elements in Water, Solids, and Biosolids by Stabilized Temperature Graphite Furnace Atomic Absorption Spectrometry. Revision 3.0. US Environmental Protection Agency, Washington, DC.

EPE, 2014. Anuário estatístico de energia elétrica 2014 - ano base 2013 [2014 Statistical yearbook of electricity - 2013 baseline year]. Empresa de Pesquisa Energética, Rio de Janeiro http://www.epe.gov.br/AnuarioEstatisticodeEnergiaEletrica/Anu\%C3\% A1rio\%20Estat\%C3\%ADstico\%20de\%20Energia\%20El\%C3\%A9trica\%202014.pdf, Accessed date: 1 November 2016.

Fernandes, B.S., Vieira, J.P.F., Contesini, F.J., Mantelatto, P.E., Zaiat, M., Pradella, J.G.C., 2017. High value added lipids produced by microorganisms: a potential use of sugarcane vinasse. Crit. Rev. Biotechnol. 37, 1048-1061.

Ferraz Jr., A.D.N., Koyama, M.H., Araújo Jr., M.M., Zaiat, M., 2016. Thermophilic anaerobic digestion of raw sugarcane vinasse. Renew. Energy 89, 245-252.

Ferreira, L.F.R., Aguiar, M.M., Messias, T.G., Pompeu, G.B., Lopez, A.M.Q., Silva, D.P., Monteiro, R.T., 2011. Evaluation of sugar-cane vinasse treated with Pleurotus sajorcaju utilizing aquatic organisms as toxicological indicators. Ecotoxicol. Environ. Saf. 74, 132-137.

Fuess, L.T., Garcia, M.L., 2014. Implications of stillage land disposal: a critical review on the impacts of fertigation. J. Environ. Manag. 145, 210-229.

Fuess, L.T., Garcia, M.L., 2015. Bioenergy from stillage anaerobic digestion to enhance the energy balance ratio of ethanol production. J. Environ. Manag. 162, 102-114.

Fuess, L.T., Kiyuna, L.S.M., Garcia, M.L., Zaiat, M., 2016. Operational strategies for long-term biohydrogen production from sugarcane stillage in continuous acidogenic packedbed reactor. Int. J. Hydrog. Energy 41, 8132-8145.

Fuess, L.T., Kiyuna, L.S.M., Ferraz Jr., A.D.N., Persinoti, G.F., Squina, F.M., Garcia, M.L., Zaiat, M., 2017a. Thermophilic two-phase anaerobic digestion using innovative fixed-bed reactor for enhanced organic matter removal and bioenergy recovery from sugarcane vinasse. Appl. Energy 189, 480-491.

Fuess, L.T., Araújo Jr., M.M., Garcia, M.L., Zaiat, M., 2017b. Designing full-scale biodigestion plants for the treatment of vinasse in sugarcane biorefineries: how phase separation and alkalinization impact biogas and electricity production costs? Chem. Eng. Res. Des. 119, 209-220.

Fuess, L.T., Rodrigues, I.J., Garcia, M.L., 2017c. Fertirrigation with sugarcane vinasse: foreseeing potential impacts on soil and water resources through vinasse characterization. J. Environ. Sci. Health A 52 (11), 1063-1072.

Fuess, L.T., Klein, B.C., Chagas, M.F., Rezende, M.C.A.F., Garcia, M.L., Bonomi, A., Zaiat, M., 2018. Diversifying the technological strategies for recovering bioenergy from the two-phase anaerobic digestion of sugarcane vinasse: an integrated technoeconomic and environmental approach. Renew. Energy 122, 674-687.

Gariglio, H.A.A., 2008. Alterações físicas e químicas e mobilidade de solutos em solos submetidos à aplicação de vinhaça proveniente da fabricação de álcool carburante [Physical and chemical changes and mobility of solutes in soils undergoing the implementation of vinasse]. (MSc dissertation). Federal University of Viçosa, Viçosa, MG, Brazil.

Goldstein, L., Hedman, B., Knowles, D., Freedman, S.I., Woods, R., Schweizer, T., 2003. Gasfired distributed energy resource technology characterizations. NREL/TP-620-34783. National Renewable Energy Laboratory, Golden, CO http://www.nrel.gov/docs/ fy04osti/34783.pdf, Accessed date: 15 August 2015.

Heywood, J.B., 1988. Internal combustion engine fundamentals. 1st ed. McGraw-Hill, New York.

IBGE, 2016. Sinopse do senso demográfico 2010 [Synopsis of the 2010 census]. Instituto Brasileiro de Geografia e Estatística http://www.censo2010.ibge.gov.br/sinopse/ index.php?dados $=10 \& u f=00$, Accessed date: 10 June 2016. 
Janke, L., Leite, A.F., Batista, K., Silva, W., Nikolausz, M., Nelles, M., Stinner, W., 2016. Enhancing biogas production from vinasse in sugarcane biorefineries: effects of urea and trace elements supplementation on process performance and stability. Bioresour. Technol. 217, 10-20.

Jayaram, V.B., Cuyvers, S., Verstrepen, K.J., Delcour, J.A., Courtin, C.M., 2014. Succinic acid in levels produced by yeast (Saccharomyces cerevisiae) during fermentation strongly impacts wheat bread dough properties. Food Chem. 151, 421-428.

Jespersen, N.D., 2007. Barron's AP Chemistry. 4th ed. Barron's Education Series Inc, New York.

Junqueira, T.L., Cavalett, O., Bonomi, A., 2016. The virtual sugarcane biorefinery - a simulation tool to support public policies formulation in bioenergy. Ind. Biotechnol. 12, 62-67.

Kahraman, S.S., Gurdal, I.H., 2002. Effect of synthetic and natural culture media on laccase production by white rot fungi. Bioresour. Technol. 82, 215-217.

Ke, S., Shi, Z., Fang, H.H.P., 2005. Applications of two-phase anaerobic degradation in industrial wastewater treatment. Int. J. Environ. Pollut. 23, 65-80.

Kiyuna, L.S.M., Fuess, L.T., Zaiat, M., 2017. Unraveling the influence of the COD/sulfate ratio on organic matter removal and methane production from the biodigestion of sugarcane vinasse. Bioresour. Technol. 232, 103-112.

Lupiañez, J.A., Machado, A., Nuñez de Castro, I., Mayor, F., 1974. Succinic acid production by yeasts grown under different hypoxic conditions. Mol. Cell. Biochem. 3 (2), 113-116.

Mayer, F.D., Feris, L.A., Marcilio, N.R., Staudt, P.B., Hoffmann, R., Baldo, V., 2015. Influence of fusel oil components on the distillation of hydrous ethanol fuel (HEF) in a bench column. Braz. J. Chem. Eng. 32, 585-593.

Melo, H.F., 2006. Resposta ao estresse ácido em leveduras da fermentação alcoólica industrial [Response to acid stress in industrial fermentation yeasts]. (PhD thesis). Federal Univeristy of Pernambuco, Recife, SP, Brazil.

Menezes, E.G.T., Alves, J.G.L.F., Valeriano, C., Guimarães, I.C., 2013. Physico-chemical and sensorial evaluation of sugarcane spirits produced using distillation residue. Braz. Arch. Biol. Technol. 56, 121-126.

Moraes, B.S., Junqueira, T.L., Pavanello, L.G., Cavalett, O., Mantelatto, P.E., Bonomi, A., Zaiat, M., 2014. Anaerobic digestion of vinasse from sugarcane biorefineries in Brazil from energy, environmental, and economic perspectives: profit or expense? Appl. Energy $113,825-835$.

Moraes, B.S., Zaiat, M., Bonomi, A., 2015. Anaerobic digestion of vinasse from sugarcane ethanol production in Brazil: challenges and perspectives. Renew Sustain. Energy Ver. 44, 888-903.

Morais, E.R., Junqueira, T.L., Sampaio, I.L.M., Dias, M.O.S., Rezende, M.C.A.F., Jesus, C.D.F., Klein, B.C., Gómez, E.O., Mantelatto, P.E., Maciel Filho, R., Bonomi, A., 2016. Biorefinery alternatives. In: Bonomi, A., Cavalett, O., Cunha, M.P., Lima, M.A.P. (Eds.), Virtual Biorefinery: An Optimization Strategy for Renewable Carbon Valorization. Springer, London, pp. 53-132.

Muñoz, R., Meier, L., Diaz, I., Jeison, D., 2015. A critical review on the state-of-the-art of physical/chemical and biological technologies for an integral biogas upgrading. Rev. Environ. Sci. Biotechnol. 14, 727-759.

Nandy, T., Shastry, S., Kaul, S.N., 2002. Wastewater management in a cane molasses distillery involving bioresource recovery. J. Environ. Manag. 65, 25-38.

Navarro, A.R., Sepúlveda, M.C., Rubio, M.C., 2000. Bio-concentration of vinasse from the alcoholic fermentation of sugar cane molasses. Waste Manag. 20, 581-585.

Oliveira, J.G., Garcia-Cruz, C.H., 2013. Properties of a biosurfactant produced by Bacillus pumilus using vinasse and waste frying oil as alternative carbon sources. Braz. Arch. Biol. Technol. 56, 155-160.

Oliveira, B.G., Carvalho, J.L.N., Cerri, C.E.P., Cerri, C.C., Feigl, B.J., 2013. Soil greenhouse gas fluxes from vinasse application in Brazilian sugarcane areas. Geoderma 200-201, 77-84.

Pereira, I.M., 1991. Estudo de alguns parâmetros para precipitação de glicerol através da complexação com zircônio em vinhaças de álcool carburante e de aguardente e em lixívias fracas de saboaria [Study of some parameters for glycerol precipitation by complexation with zirconium in vinasses from fuel alcohol and spirits and weak leaches of soap manufacture]. (MSc dissertation). University of Campinas, Campinas, SP, Brazil.

Pires, J.F., Ferreira, G.M.R., Reis, K.C., Schwan, R.F., Silva, C.F., 2016. Mixed yeasts inocula for simultaneous production of SCP and treatment of vinasse to reduce soil and fresh water pollution. J. Environ. Manag. 182, 455-463.
Reis, C.M., Carosia, M.F., Sakamoto, I.K., Varesche, M.B.A., Silva, E.L., 2015. Evaluation of hydrogen and methane production from sugarcane vinasse in an anaerobic fluidized bed reactor. Int. J. Hydrog. Energy 40, 8498-8509.

Richards, L.A., 1954. Diagnosis and Improvement of Saline and Alkali Soils. United States Department of Agriculture, Washington, DC

Salomon, K.R., Lora, E.E.S., Rocha, M.H., del Olmo, O.A., 2011. Cost calculations for biogas from vinasse biodigestion and its energy utilization. Sugar Ind. 136, 217-223.

Santos, S.C., Rosa, P.F.R., Sakamoto, I.K., Varesche, M.B.A., Silva, E.L., 2014a. Continuous thermophilic hydrogen production and microbial community analysis from anaerobic digestion of diluted sugar cane stillage. Int. J. Hydrog. Energy 39, 9000-9011.

Santos, S.C., Rosa, P.F.R., Sakamoto, I.K., Varesche, M.B.A., Silva, E.L., 2014b. Organic loading rate impact on biohydrogen production and microbial communities at anaerobic fluidized thermophilic bed reactors treating sugarcane stillage. Bioresour. Technol. 159, 55-63.

Santos, R.R., Araújo, O.Q.F., Medeiros, J.L., Chaloub, R.M., 2016. Cultivation of Spirulina maxima in medium supplemented with sugarcane vinasse. Bioresour. Technol. 204, $38-48$.

Siegumfeldt, H., Rechinger, K.B., Jakobsen, M., 2000. Dynamic changes of intracellular pH in individual lactic acid bacterium cells in response to a rapid drop in extracellular pH. Appl. Environ. Microbiol. 66, 2330-2335.

Silva, W.P., Almeida, C.D.G.C., Rolim, M.M., Silva, E.F.F., Pedrosa, E.M.R., Silva, V.G.F., 2014 Monitoramento da salinidade de águas subterrâneas em várzea cultivada com canade-açúcar fertirrigada com vinhaça [Monitoring of groundwater salinity in lowland under sugarcane cultivation fertigated with vinasse]. R. Bras. Eng. Agric. Ambient 18, 394-401.

Siqueira, L.M., Damiano, E.S.G., Silva, E.L., 2013. Influence of organic loading rate on the anaerobic treatment of sugarcane vinasse and biogas production in fluidized bed reactor. J. Environ. Sci. Health A 48, 1707-1716.

Souza, M.E., Fuzaro, G., Polegato, A.R., 1992. Thermophilic anaerobic digestion of vinasse in pilot plant UASB reactor. Water Sci. Technol. 25 (7), 213-222.

Tasso Jr., L.G., Marques, M.O., Franco, A., Nogueira, G.A., Nobile, F.O., Camilotti, F., Silva, A.R., 2007. Produtividade e qualidade de cana-de-açúcar cultivada em solo tratado com lodo de esgoto, vinhaça e adubos minerais [Yield and quality of sugar cane cultivated in sewage sludge, vinasse and mineral fertilization supplied soil]. Eng. Agric. 27, 276-283.

Tejada, M., Gonzalez, J.L., 2006. Effects on two beet vinasse forms on soil physical properties and soil loss. Catena $68,41-50$

Tejada, M., Moreno, J.L., Hernandez, M.T., Garcia, C., 2007. Application of two beet vinasse forms in soil restoration: effects on soil properties in an arid environment in southern Spain. Agric. Ecosyst. Environ. 119, 289-298.

Thoukis, G., Ueda, M., Wright, D., 1965. The formation of succinic acid during alcoholic fermentation. Am. J. Enol. Vitic. 16 (1), 1-8.

United Nations, 2016. Framework Convention on Climate Change. Global Warming Potentials. http://unfccc.int/ghg_data/items/3825.php, Accessed date: 10 June 2016.

von Sperling, M., 2007. Wastewater Characteristics, Treatment and Disposal. IWA Publishing, London.

WHO, 2006. Guidelines for the Safe Use of Wastewater, Excreta and Greywater. World Health Organization, Geneva.

Wilkie, A.C., Riedesel, K.J., Owens, J.M., 2000. Stillage characterization and anaerobic treatment of ethanol stillage from conventional and cellulosic feedstocks. Biomass Bioenergy 19, 63-102.

Zelle, R.M., de Hulster, E., van Winden, W.A., de Waard, P., Dijkema, C., Winkler, A.A. Geertman, J.M., Pronk, J.T., van Maris, A.J., 2008. Malic acid production by Saccharomyces cerevisiae: engineering of pyruvate carboxylation, oxaloacetate reduction, and malate export. Appl. Environ. Microbiol. 74, 2766-2777.

Zhou, J., Xing, J., 2015. Effect of electron donors on the performance of haloalkaliphilic sulfate-reducing bioreactors for flue gas treatment and microbial degradation patterns related to sulfate reduction of different electron donors. Biochem. Eng. J. 96, 14-22.

Zolin, C.A., Paulino, J., Bertonha, A., Freitas, P.S.L., Folegatti, M.V., 2011. Estudo exploratório do uso da vinhaça ao longo do tempo. I. Características do solo. [Exploratory study of the stillage use along the time. I. Characteristics of the soil]. R. Bras. Eng. Agric. Ambient. 15, 22-28. 